\title{
Reassessing zircon-monazite thermometry with thermodynamic modelling: insights from the Georgetown igneous complex, NE Australia
}

\author{
S. Volante ${ }^{1,2,4}$ (D) W. J. Collins ${ }^{1} \cdot$ E. Blereau ${ }^{3} \cdot$ A. Pourteau ${ }^{1} \cdot$ C. Spencer ${ }^{1} \cdot$ N. J. Evans ${ }^{3} \cdot$ V. Barrote $^{4,3} \cdot$ A. R. Nordsvan $^{1,5}$. \\ Z.-X. Li ${ }^{1} \cdot$ J. Li ${ }^{1}$
}

Received: 14 June 2020 / Accepted: 15 October 2020 / Published online: 5 November 2020

(c) The Author(s) 2020

\begin{abstract}
Accessory mineral thermometry and thermodynamic modelling are fundamental tools for constraining petrogenetic models of granite magmatism. U-Pb geochronology on zircon and monazite from S-type granites emplaced within a semicontinuous, whole-crust section in the Georgetown Inlier (GTI), NE Australia, indicates synchronous crystallisation at $1550 \mathrm{Ma}$. Zircon saturation temperature $\left(T_{\mathrm{zr}}\right)$ and titanium-in-zircon thermometry $\left(T_{\text {(Ti-zr })}\right)$ estimate magma temperatures of $\sim 795 \pm 41{ }^{\circ} \mathrm{C}\left(T_{\mathrm{zr}}\right)$ and $\sim 845 \pm 46^{\circ} \mathrm{C}\left(T_{\text {(Ti-zr })}\right)$ in the deep crust, $\sim 735 \pm 30^{\circ} \mathrm{C}\left(T_{\mathrm{zr}}\right)$ and $\sim 785 \pm 30{ }^{\circ} \mathrm{C}\left(T_{(\mathrm{Ti}-\mathrm{zr})}\right)$ in the middle crust, and $\sim 796 \pm 45^{\circ} \mathrm{C}\left(T_{\mathrm{zr}}\right)$ and $\sim 850 \pm 40{ }^{\circ} \mathrm{C}\left(T_{\text {(Ti-zr }}\right)$ in the upper crust. The differing averages reflect ambient temperature conditions $\left(T_{\mathrm{zr}}\right)$ within the magma chamber, whereas the higher $T_{(\mathrm{Ti}-\mathrm{zr})}$ values represent peak conditions of hotter melt injections. Assuming thermal equilibrium through the crust and adiabatic ascent, shallower magmas contained $4 \mathrm{wt} \% \mathrm{H}_{2} \mathrm{O}$, whereas deeper melts contained $7 \mathrm{wt} \% \mathrm{H}_{2} \mathrm{O}$. Using these $\mathrm{H}_{2} \mathrm{O}$ contents, monazite saturation temperature $\left(T_{\mathrm{mz}}\right)$ estimates agree with $T_{\mathrm{zr}}$ values. Thermodynamic modelling indicates that plagioclase, garnet and biotite were restitic phases, and that compositional variation in the GTI suites resulted from entrainment of these minerals in silicic $\left(74-76 \mathrm{wt} \% \mathrm{SiO}_{2}\right) \mathrm{melts}$ At inferred emplacement $P-T$ conditions of $5 \mathrm{kbar}$ and $730{ }^{\circ} \mathrm{C}$, additional $\mathrm{H}_{2} \mathrm{O}$ is required to produce sufficient melt with compositions similar to the GTI granites. Drier and hotter magmas required additional heat to raise adiabatically to uppercrustal levels. S-type granites are low- $T$ mushes of melt and residual phases that stall and equilibrate in the middle crust, suggesting that discussions on the unreliability of zircon-based thermometers should be modulated.
\end{abstract}

Keywords Zircon and monazite thermometry $\cdot$ Water content $\cdot$ Granitic melts $\cdot$ Complete crustal section $\cdot$ Phase equilibria diagrams

Communicated by Daniela Rubatto.

Electronic supplementary material The online version of this article (https://doi.org/10.1007/s00410-020-01752-7) contains supplementary material, which is available to authorized users.

S. Volante

silvia.volante@rub.de

1 Earth-Dynamics Research Group, Australian Research Council Centre of Excellence for Core To Crust Fluid Systems (CCFS) and The Institute for Geoscience Research (TIGeR), School of Earth and Planetary Sciences, Curtin University, Perth, WA 6845, Australia

2 Institute of Geology, Mineralogy and Geophysics, Ruhr-Universität Bochum, Universitätsstraße 150, 44801 Bochum, Germany

\section{Introduction}

Crustal anatexis, accompanied by melt extraction and magma ascent to upper-crustal levels, constitutes the most important mechanism for geochemical differentiation

3 John de Laeter Centre, School of Earth and Planetary Sciences, Curtin University, GPO Box U1987, Perth, WA 6845 , Australia

4 ISOTOPIA Lab, School of Earth, Atmosphere and Environment, Monash University, Wellington Rd, Clayton, VIC 3800, Australia

5 Department of Earth Sciences, University of Hong Kong, Pokfulam, Hong Kong 
of the continental crust (e.g., Vielzeuf et al. 1990). The resultant magmas can be derived either from metasedimentary (S-type) or metaigneous (I-type) sources (Chappell 1984; Chappell and White 1992). Peraluminous, K-rich (S-type) granitic magmas that intrude at shallow crustal levels or that erupt, are widely modelled as hightemperature $\left(>800{ }^{\circ} \mathrm{C}\right)$ melt products form under fluidabsent melting conditions at granulite facies (e.g., Clemens et al. 2020; Le Breton and Thompson 1988; Vielzeuf and Montel 1994). However, field and petrological observations of large $S$-type granitic batholiths emplaced in high-grade migmatitic terranes (i.e., mid- to low-crustal levels) commonly point to lower temperatures $\left(\leq 750{ }^{\circ} \mathrm{C}\right)$ at upper amphibolite facies, which is possible if waterfluxed melting conditions are considered (e.g., Weinberg and Hasalová 2015).

Estimating the temperature and water content of granitic magmas is difficult. Clemens (1984) divided the commonly used methods into four main groups: (1) measurement of quenched magma (i.e., volcanic glass) by gravimetric means; (2) geological inference in a field area where both anatectic source rocks and granitoids crystallised from the partial melts can be studied; (3) experimental determinations (Clemens 1984 and reference therein); 4) Thermodynamic calculations (e.g., Harley 2008; Wheller and Powell 2014; White et al. 2007).

Thermometry of accessory mineral phases such as zircon (Boehnke et al. 2013; Ferry and Watson 2007; Fu et al. 2008; Watson and Harrison 2005) and monazite (Montel 1993; Stepanov et al. 2012) have commonly not been combined to their full potential for melt temperature estimation. Indeed, zircon saturation temperatures are often thought to underestimate magmatic temperatures, which is the case if the melts are zircon undersaturated (Miller et al. 2003). However, most silica-rich ( $>65 \mathrm{wt} \% \mathrm{SiO}_{2}$ ) granitic magmas show peak $\mathrm{Zr}$ contents decrease with increasing magmatic silica content (e.g., Collins et al. 2016; McDowell et al. 2014). Siégel et al. (2018) suggested that $T_{\mathrm{zr}}$ consistently underestimates actual $T_{\text {Magma }}$, but they assume that granitic magmas are produced by fractional crystallisation of mafic magmas over an extended temperature range, which is not the case for most granites, particularly for S-type. Schiller and Finger (2019) used rhyolite-MELTS (Gualda et al. 2012) and Perple_X (Connolly and Petrini 2002) modelling to suggest that temperature estimates using Ti-in-zircon are commonly too low in many granites. However, they assume that granitic magmas are generated by fluid-absent melting, especially by biotite breakdown at $\sim 850{ }^{\circ} \mathrm{C}$ or above. Finally, monazite saturation thermometry is not as commonly applied as zircon thermometry, although studies have shown that both zircon and monazite thermometry are in general agreement for peraluminous (S-type) granitoids (Acosta-Vigil et al. 2010; Jung and Pfänder 2007; Montel 1993).
In this contribution, the reliability of zircon and monazite thermometry in granitic magmas is assessed using a natural, crustal-scale magmatic system from the Georgetown Inlier (GTI), North Queensland, Australia and applying thermodynamic modelling. The $P-T$ conditions of S-type granite generation in the GTI are established from field relations and metamorphic petrology of a $30 \mathrm{~km}$-thick, continuous crustal section (Volante et al. 2020a), which are used to determine a range of melt compositions for relevant $P-T-X_{(\mathrm{H} 2 \mathrm{O})}$ conditions. Results from phase diagrams are compared to the GTI granite compositions to more precisely establish the temperature of magma generation, which is used to reassess zircon and monazite geothermometers for these S-type granites.

\section{Geological setting}

The Palaeoproterozoic-Mesoproterozoic Georgetown Inlier (GTI) in NE Australia comprises poly-deformed metasedimentary, metamafic and granitic rocks, together with undeformed volcanic and intrusive felsic rocks. The volcanic rocks in the west - the Croydon Volcanic Groupunconformably overlie the metasedimentary sequence of the Etheridge Group (Withnall and Hutton 2013), while the co-magmatic granitic plutons largely intruded the polydeformed and metamorphosed $>1700-1620$ Ma stratigraphic successions at 1560-1550 Ma (Fig. 1; Black and McCulloch 1990; Neumann and Kositcin 2011; Withnall and Hutton 2013). The lower part of the Etheridge Group was deposited between c. 1700-1650 Ma and is interlayered with c. $1665 \mathrm{Ma}$ (Baker et al. 2010) mafic lava flows and intruded by similarl aged dykes, and sills (e.g., the Deadhorse Metabasalts and Cobbold Metadolerite; Withnall 1985). The lower part of the metasedimentary sequence is regarded as the protolith of the high-grade migmatite exposed in the eastern part of the inlier (e.g., the Einasleigh Metamorphics; Fig. 1; Withnall et al. 1988). The Etheridge Group can be mapped from low-grade shales and sandstones in the western domain to high-grade metapelites and psammites in the eastern domain (Volante et al. 2020a).

Recently, metamorphic domains were identified and contoured in the GTI, which demonstrated that the terrain was a semi-continuous crustal section (Volante et al. 2020a). Accordingly, the inlier was divided into three main metamorphic domains, representing distinct crustal levels: (1) the western greenschist-facies domain equilibrated at $<3$ kbar, with the 1550 Ma Croydon Volcanic Group erupted upon the Etheridge Group; (2) the central medium- to upper amphibolite-facies domain, which formed at 4-6 kbar, and in which extensive granitic sheets and discordant plutons of the S-type Georgetown supersuites intruded (Champion 1991); (3) eastern upper amphibolite- to granulite- facies domain, dominated by migmatitic gneisses, which equilibrated at 8-9 kbar. 


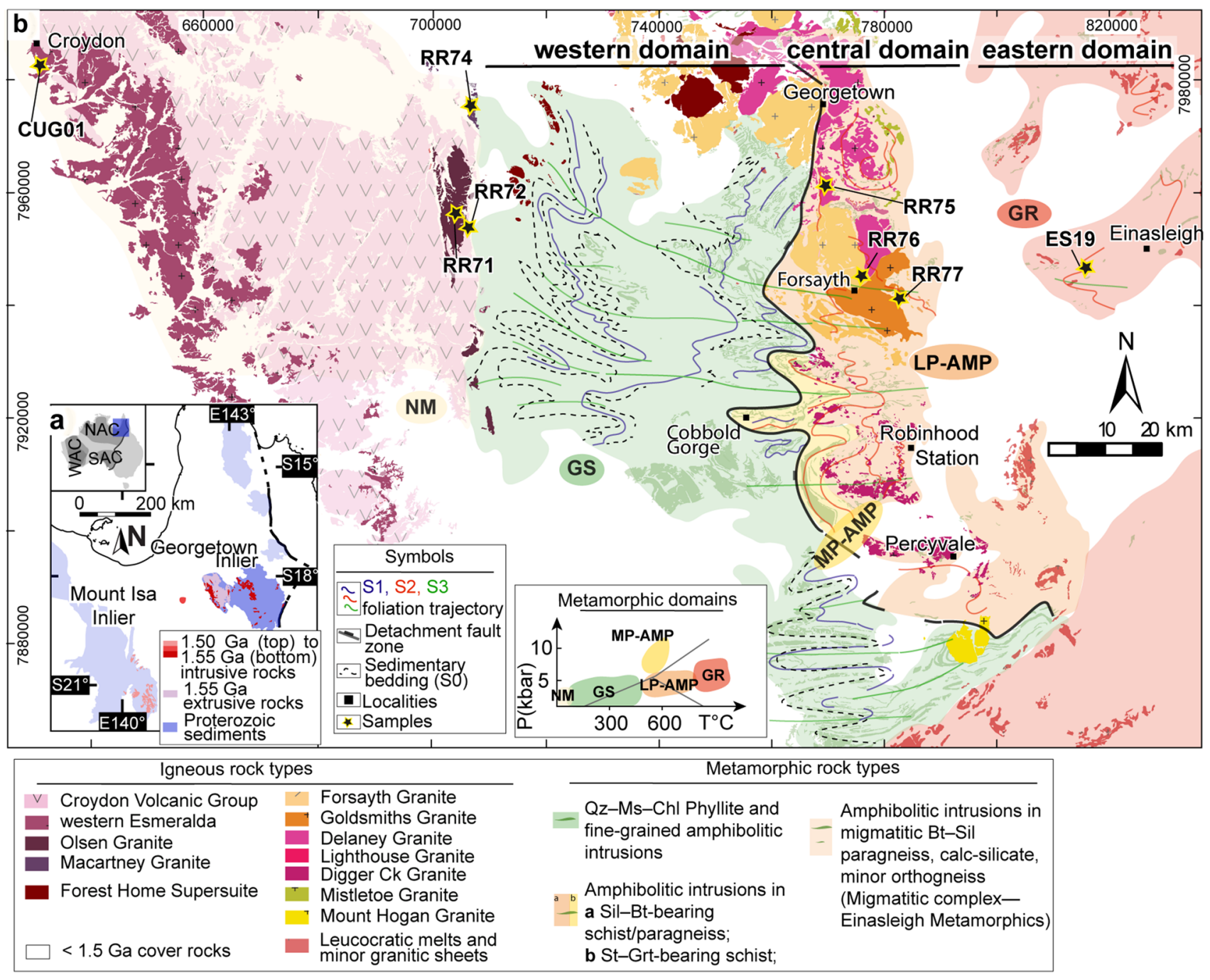

Fig. 1 a Regional map of the northeast Australian Proterozoic inliers (adapted after Volante et al. 2020a). The discontinuous black line 'Tasman Line' depicts the eastern margin of the North Australia Craton (NAC). NAC, North Australian Craton; SAC, South Australian Craton; WAC, Western Australian Craton. b Metamorphic and structural map of the GTI with the location of the studied samples (black

S-type granites in the GTI have been dated in several geochronological studies (Black and McCulloch 1990; Black and Withnall 1993; Neumann and Kositcin 2011), all yielding a consistent zircon crystallisation age range of 1560-1540 Ma (D2/M2). Previous classifications divided them into two main groups based on their structural features, mineral assemblage, and contact relationships: the Esmeralda and the Forsayth supersuites (Champion 1991; Withnall and Hutton 2013). The Esmeralda Supersuite comprises the Esmeralda pluton, other smaller associated granitic bodies (e.g., the Olsen and Macartney granites), and the felsic extrusive rocks of the Croydon Volcanic Group, which all outcrop west of the greenschist-facies western domain (Fig. 1). These western granites and volcanic rocks stars). For the metamorphic domains: NM, non-metamorphosed; GS, greenschist-facies; MP-AMP, medium-pressure amphibolite-facies; LP-AMP, low-pressure amphibolite facies; GR, granulite facies. Mineral abbreviations follow those suggested by Whitney and Evans (2010)

are generally undeformed to weakly deformed. The Forsayth Supersuite comprises most of the granites located in the central domain and was derived from the melting of the surrounding high-grade metasedimentary host rocks (Black and McCulloch 1990). These granites are foliated, biotite-muscovite-bearing, are characterised by medium-to coarse-grained K-feldspar megacrysts. Field relationships suggest that they were emplaced syn- to late- S2 foliation development (Volante et al. 2020b).

\section{Field sampling and petrography}

Granites and volcanic samples were collected along an E-W transect in the GTI (Figs. 1, 2). The westernmost samples 

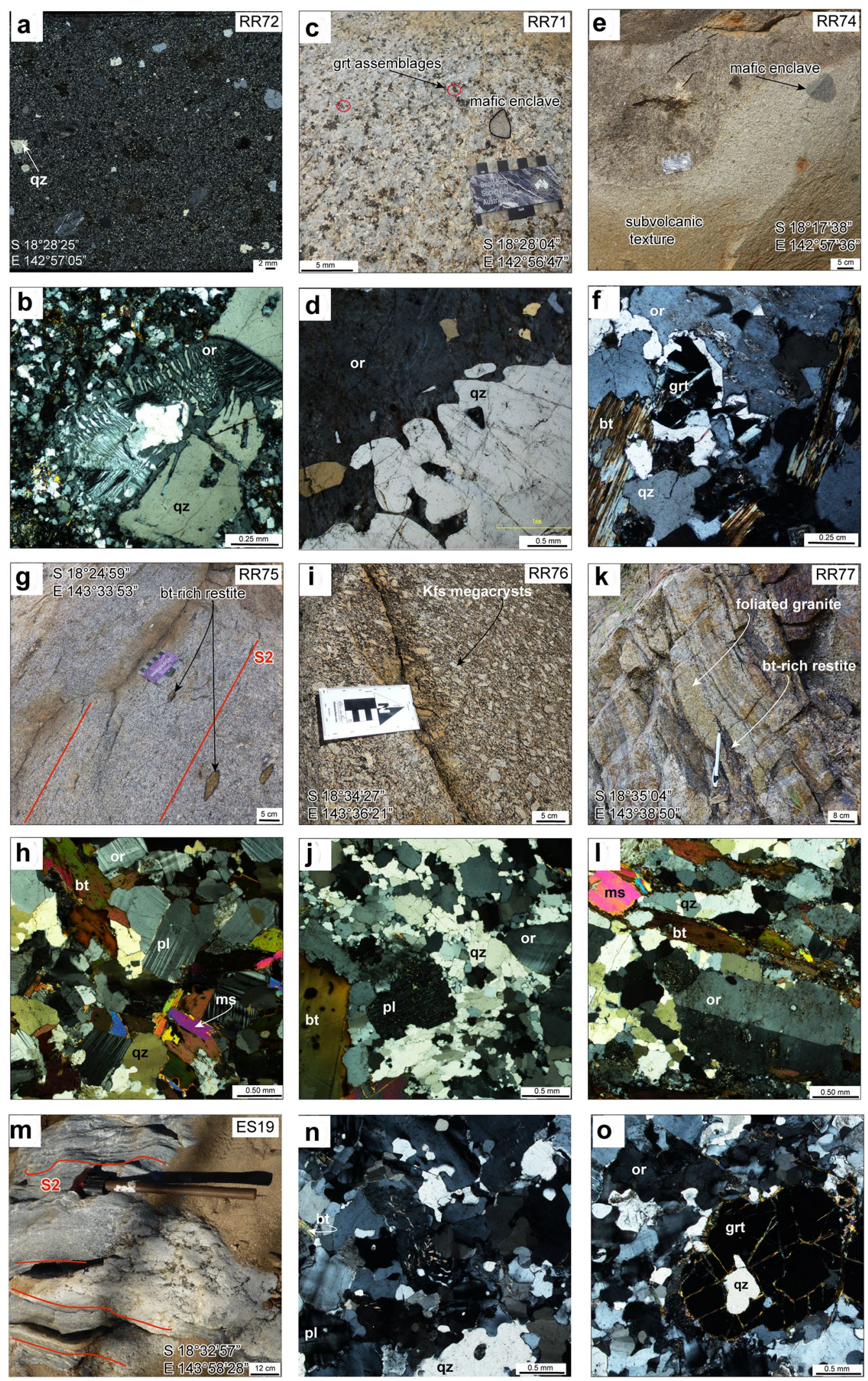
४Fig. 2 Field photos and representative photomicrographs in crosspolarised light of the studied samples from the western to the eastern domains. a RR72 (Croydon volcanic rock): non-deformed rhyolite. b Qz-Or intergrowth. c RR71 (Olsen Granite): Kfs- megacrysts Grt-Btbearing granite with mafic enclaves. d Qz-Or lobate magmatic texture. e RR74 (Macartney Granite): subvolcanic texture of Grt-bearing granite with mafic enclaves. f Grt with Qz corona in Or phenocryst. $\mathbf{g}$ RR75 (Delaney Granite): foliated Bt-bearing granite with mafic xenoliths. h Deformation twins in Pl and annealing in Qz. i RR76 (Forsayth Granite): foliated Kfs-megacrysts granite. j Recrystallised Qz and deformed Bt. k RR77 (Goldsmiths Granite): Foliated Bt-bearing granite. 1 Recrystallised $\mathrm{Bt}$ (minor $\mathrm{Ms}$ ) and Qz define tectonic fabric that wraps Or phenocrysts. m ES19 (leucocratic layer): leucocratic layer subparallel to the S2 foliation in migmatitic paragneiss. $\mathbf{n}$ Granular fine-grained texture defined by Qz, Pl, Or, Grt, and minor Bt. o Euhedral Grt with round-shaped quartz inclusions

are part of the Esmeralda Supersuite (CUG01 from the Esmeralda Granite; RR71 from the Olsen Granite), which consists of megacrystic garnet-biotite-bearing, commonly undeformed or weakly deformed granites and includes the overlying non-foliated volcanic rocks (RR72; Croydon Volcanic Group). The Macartney Granite (RR74) is a weakly foliated, subvolcanic garnet-bearing granite with common mafic enclaves, which intruded low-grade metasedimentary rocks of the upper-crustal western domain. In the central domain, three samples of variably foliated biotite-muscovite-bearing (S-type) granites, which had intruded highgrade sillimanite-biotite gneisses, were collected (RR75, RR76, and RR77; Delaney, Forsayth and Goldsmiths granites, respectively). All three samples are partially recrystallised. In the eastern domain, a leucocratic layer (ES19) in a migmatitic paragneiss was sampled (ES18), and inferred to represent the partial melt portion of the metasedimentary rock was sampled. Similar magmatic zircon ages have been previously obtained for partial melting in the eastern domain and the S-type granites of the central domain (Black et al. 2005; Neumann and Kositcin 2011; Withnall and Hutton 2013; Volante et al. 2020a).

The analysed samples are listed in the Electronic supplementary material Table S1. Mineral abbreviations used throughout the text, tables, and figures follow those suggested by Whitney and Evans (2010).

\section{Western domain}

The Croydon Volcanic Group (RR72; Fig. 2a, b) is extensively exposed in the western domain (Fig. 1) where the rocks are intruded by the co-magmatic Esmeralda Supersuite (CUG01, RR71, RR74). The volcanic rocks of the Croydon Volcanic Group are characterised by medium- to coarsegrained orthoclase phenocrysts that are simply twinned, with perthitic exsolution. Localised granophyric intergrowth of quartz-K-feldspar occurs (Fig. 2b). The presence of undulose, myrmekitic texture and finely recrystallised grain boundaries suggests that the rock experienced weak deformation under greenschist-facies conditions. Zircon and monazite occur both in the groundmass and as inclusions in plagioclase and orthoclase phenocrysts.

The western plutons (Fig. 2c-f) of the Esmeralda Supersuite contain dispersed sub-rounded mafic enclaves (Fig. 2c, e) that are characterised by dark rims, probably formed during a reaction between the enclave and the melt. Subhedral plagioclase is an early-formed phase relative to most minerals. Quartz and K-feldspar megacrysts share straight to lobate contacts (Fig. 2d), which indicates these two phases grew in equilibrium during magmatic crystallization, probably in a subvolcanic magma chamber (Vernon 2004), whereas local granophyric intergrowths suggest that quartz and K-feldspar crystallised last. Garnet is partially replaced by aggregates of brown biotite grains sharing straight boundaries with coronitic quartz (Fig. 2f). Ubiquitous quartz grains are characterised by weak undulose extinction, indicating they are weakly deformed, and alternation is widespread. The delicate fine-grained texture of sample RR74, albeit overprinted by secondary minerals, suggests that the granite was emplaced in a subvolcanic environment (Fig. 2e). Also, the relatively abundant mafic enclaves in these western granites suggest that the final emplacement was associated with an infusion of mafic magma. Accessory minerals such as zircon grains are mostly prismatic and occur as inclusions in biotite, garnet, or quartz, whereas monazite grains are commonly included in biotite and orthoclase.

\section{Central domain}

Central domain granites are variably foliated (samples RR75, RR76, and RR77; Fig. 2g, 1), and either host sillimanite-bearing schist/gneiss xenoliths or are enclosed as sheets and lenses in schistose metasedimentary rocks (Fig. 2k). The foliation in the granitic samples is generally defined by the alignment of recrystallised quartz, biotite, and minor white mica, and xenoliths of biotite-rich clots (Fig. 2g), concordant with the regional S2 high-grade gneissic fabric (Fig. 2k).

In these plutons, subhedral plagioclase occurs with weak oscillatory zoning. Locally plagioclase twins are bent or lenticular (e.g., deformation twins) suggesting local, intracrystalline deformation under subsolidus conditions. Perthitic K-feldspar megacrysts, partially re-ordered to microcline, define a magmatic flow orientation (Fig. 2i). Quartz is fine- to coarse-grained. The latter usually show undulose extinction and sub-grain neoblasts with a chess board texture suggesting progressive dynamic recrystallization (Fig. 2h). Fine-grained, recrystallized aggregates of quartz define an anastomosing foliation around K-feldspar megacrysts (Fig. 2j). Quartz-albite myrmekitic texture and fine-grained recrystallized biotite and quartz are localized at the high-strain grain boundaries of K-feldspar phenocrysts. 
Coarse-grained magmatic biotite and minor white mica crystals show undulose extinction and strain bands, indicating intracrystalline deformation. Biotite is also locally recrystallised as fine-grained aggregates with white mica, and defines the tectonic fabric (S2) with aggregates of recrystallized quartz (Fig. 2l).

\section{Eastern domain}

The representative sample for the eastern domain (ES19) is a leucocratic layer sub-parallel to the dominant migmatitic foliation S2 in the paragneiss (ES18) of the Einasleigh area (Figs. 1, 2m). Plagioclase growth twins locally show flameshaped twins, indicating solid-state deformation. Perthitic orthoclase locally developed microcline-type texture, confirming subsolidus deformation, consistent with the presence of vermicular quartz-K-feldspar intergrowths (Fig. 2n) defining myrmekitic textures at the contact between deformed orthoclase and quartz. Quartz occurs as fine anhedral grains, as inclusions in larger plagioclase and orthoclase grains (Fig. 2n), and locally in garnet (Fig. 2o). Sample ES19 is interpreted to have formed during partial melting of the host metasedimentary rocks and is therefore comparable to the granite samples in the central and western domains that are also thought to have formed by partial melting of the host metasedimentary rocks (e.g., Black and McCulloch 1990).

\section{Methods}

The analytical methods used in this study are briefly presented below, and a detailed description is presented in the Appendix in ESM.

\section{Secondary high-resolution ion microprobe (SHRIMP) $\mathrm{U}-\mathrm{Pb}$ geochronology}

Zircon and monazite grains in mounted samples were characterized by cathodoluminescence (CL) imaging and backscattered electron (BSE) microscopy, respectively, using the Mira3, at the Microscopy and Microanalysis Facility at the John de Laeter Centre (JdLC), Curtin University (Appendix Figs. S1 and S2 in ESM). Samples were analysed using the SHRIMP II at the JdLC, Curtin University. Results for both zircon and monazite are plotted in Concordia diagrams with uncertainty ellipses of $95 \%$ confidence interval (Fig. 3a-h). A complete list of the analysed samples can be found in the Electronic supplementary material Table S2.

\section{LA-SS-ICPMS of zircon and monazite: trace elements}

Trace elements by laser ablation split stream inductively coupled plasma mass spectrometry (LA-SS-ICPMS) were analysed for different zircon and monazite grains from those used in the SHRIMP analysis. Samples were analysed over two sessions for monazite (both with the same analytical conditions) and one session for zircon. In the zircon and monazite rare earth element (REE) plots, the analysed data were normalized against the chondrite values of Anders and Grevesse (1989), denoted by $X_{N}$ where $X$ is the element in question and ${ }_{N}$ indicates the normalized value (Appendix Fig. S3 in ESM). A complete list of the analysed samples can be found in Electronic supplementary material Table S3.

\section{Bulk-rock geochemical data}

Bulk-rock chemical data for the Croydon Volcanic Group, the Esmeralda Supersuite (the Esmeralda, Nonda, Olsen, and Macartney granites), the Forsayth Supersuite (the Delaney, Lighthouse, Mistletoe, Forsayth, Goldsmiths, Digger Creek granites), and the leucocratic layers within migmatitic paragneiss in the eastern domain of the GTI are from the Geoscience Australia OZCHEM database (Champion et al. 2007; https://portal.ga.gov.au/persona/eftf). The data utilised are listed in the Electronic supplementary material Table S5. In addition, samples of the Olsen Granite (RR71), Croydon Volcanic Group (RR72), Macartney Granite (RR74), Delaney Granite (RR75), Forsayth Granite (RR76), Goldsmiths Granite (RR77), and a leucocratic layer in the migmatitic complex (ES19) analysed by SHRIMP were also analysed for major oxides and loss-on-ignition (LOI) (Electronic supplementary material Table S5) by Bureau Veritas (Perth, Western Australia).

\section{Phase equilibria modelling}

Phase equilibria calculations were conducted to constrain the petrogenesis of the S-type granites and to understand the role of $\mathrm{H}_{2} \mathrm{O}$ within hydrous crust in terms of melt volumes. The two starting compositions (Table 1) were chosen to represent common felsic rock types in the GTI from the midcrustal central domain to the lower-crustal eastern domain. To represent the central domain, a modified version of the average metapelitic composition (MAMC; see 1Appendix in ESM) from Boger and Hansen (2004, in Table 1 as Average (RR)) was considered for the metasedimentary rocks in the Robertson River area (Table 1 this study; see also Appendix in ESM). Sample ES18 was chosen to model the composition and $\mathrm{H}_{2} \mathrm{O}$ content of granitic melts generated in the lower crust at (i.e. c. 8 kbar) in the eastern domain (Volante et al. 2020a). The petrological evolution of the two compositions was modelled using $P-T$ and $T-X$ pseudosections calculated in THERMOCALC 3.40 (Holland and Powell 2011). The calculations were undertaken in the chemical system $\mathrm{MnO}-\mathrm{Na}_{2} \mathrm{O}-\mathrm{CaO}-\mathrm{K}_{2} \mathrm{O}-\mathrm{FeO}-\mathrm{MgO}-\mathrm{A}$ $\mathrm{l}_{2} \mathrm{O}_{3}-\mathrm{SiO}_{2}-\mathrm{H}_{2} \mathrm{O}-\mathrm{TiO}_{2}-\mathrm{O}$ (MnNCKFMASHTO) with the $\mathrm{i}$ 
Fig. 3 a-h $\mathrm{U}-\mathrm{Pb}$ Concordia diagrams showing the SHRIMP spot analyses in zircon and monazite and single populationweighted mean ${ }^{207} \mathrm{~Pb} /{ }^{206} \mathrm{~Pb}$ age. RR72: Croydon volcanic rock in the western domain; RR71 the Olsen Granite in the western domain; RR77: the Goldsmiths Granite in the central domain; ES19: Leucocratic layer in the eastern domain. Data point uncertainty ellipses are $2 \sigma$. Both inherited (in blue) and magmatic (in red for zircon and green for monazite) ages with $<10 \%$ discordance are plotted

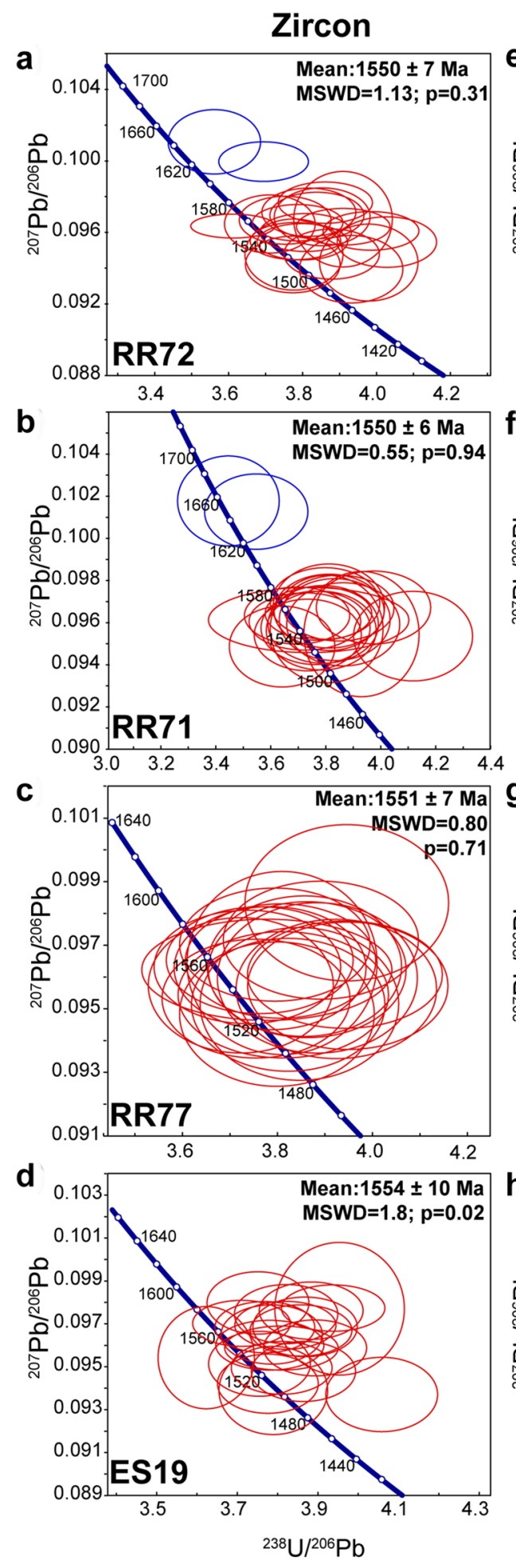

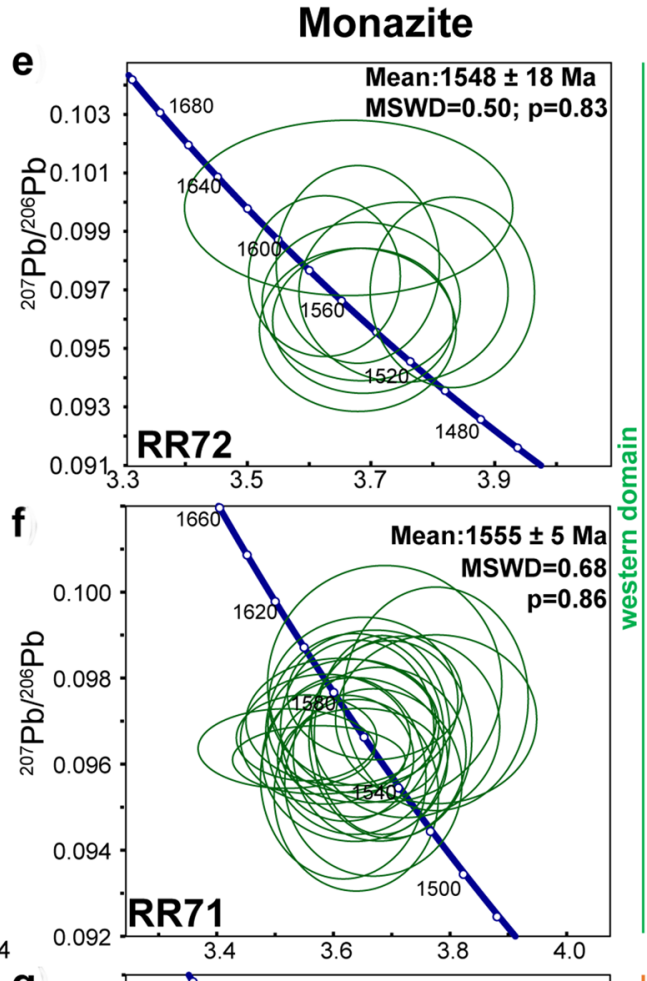
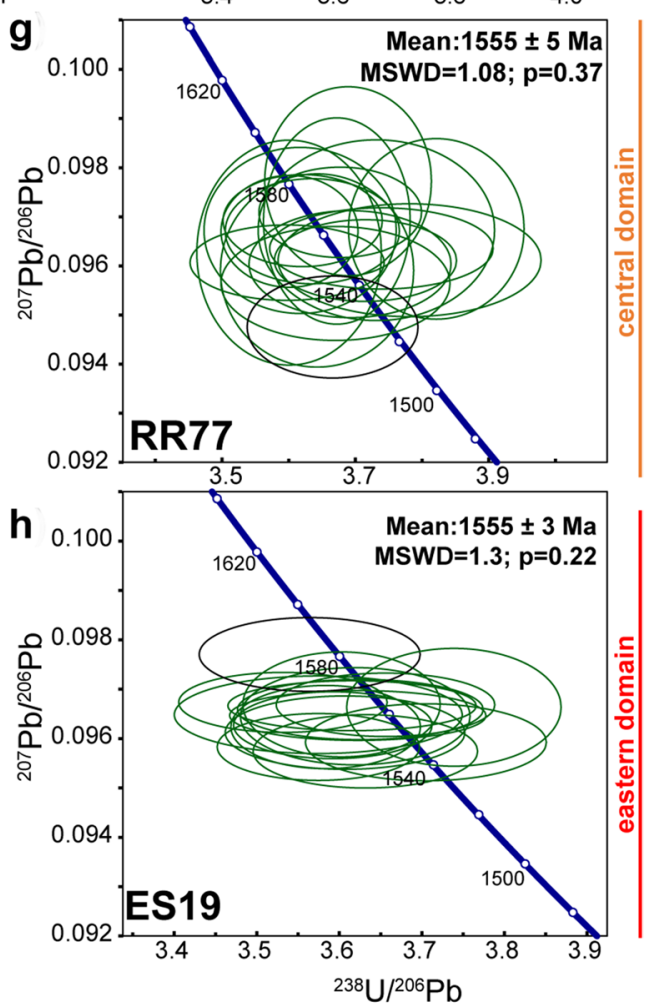

nternally consistent dataset of Holland and Powell (2011) (specifically the tc-ds62 dataset generated on 06/02/2014). Activity-composition models are from White et al. (2014).

A $T-X_{\mathrm{H} 2 \mathrm{O}}$ pseudosection (at $5 \mathrm{kbar}$ and $650-850{ }^{\circ} \mathrm{C}$ ) was constructed for MAMC to illustrate the role of $\mathrm{H}_{2} \mathrm{O}$ on the partial melting of metasedimentary rocks in the
GTI. The $T-X_{\mathrm{H} 2 \mathrm{O}}$ pseudosection used a composition that varied from $X=0.51 \mathrm{wt} \% \mathrm{H}_{2} \mathrm{O}(1.89 \mathrm{~mol} \%)$ to $X=2.11$ wt\% (7.45 mol\%) that corresponds to the measured water content of MAMC (see Table 1). The composition of MAMC corresponds to $X=2.11 \mathrm{wt} \%$ within the $T-X_{\mathrm{H} 2 \mathrm{O}}$ pseudosection. 
Table 1 Normalised XRF data used in phase equilibria modelling

\begin{tabular}{|c|c|c|c|c|c|c|c|c|c|c|c|c|c|}
\hline & Sample ID & $\mathrm{Ox}$ & $\mathrm{H}_{2} \mathrm{O}$ & $\mathrm{SiO}_{2}$ & $\mathrm{Al}_{2} \mathrm{O}_{3}$ & $\mathrm{CaO}$ & $\mathrm{MgO}$ & $\mathrm{FeO}$ & $\mathrm{K}_{2} \mathrm{O}$ & $\mathrm{Na}_{2} \mathrm{O}$ & $\mathrm{TiO}_{2}$ & $\mathrm{MnO}$ & $\mathrm{O}$ \\
\hline \multirow{4}{*}{$\begin{array}{l}\text { Modified average metapelitic composi- } \\
\text { tion (MAMC) after Boger and Hansen } \\
(2004)\end{array}$} & \multirow[t]{2}{*}{$X=0$} & wt $\%$ & 0.51 & 63.82 & 19.70 & 0.36 & 2.09 & 6.01 & 4.72 & 0.64 & 0.69 & 0.13 & 1.32 \\
\hline & & $\mathrm{mol} \%$ & 1.89 & 70.57 & 12.84 & 0.43 & 3.45 & 5.56 & 3.33 & 0.69 & 0.57 & 0.12 & 0.55 \\
\hline & \multirow[t]{2}{*}{$X=1$ and Fig. $7 \mathrm{a}$} & $\mathrm{wt} \%$ & 2.11 & 62.80 & 19.38 & 0.36 & 2.06 & 5.91 & 4.64 & 0.63 & 0.68 & 0.12 & 1.30 \\
\hline & & $\mathrm{mol} \%$ & 7.45 & 66.58 & 12.11 & 0.41 & 3.25 & 5.24 & 3.14 & 0.65 & 0.54 & 0.11 & 0.52 \\
\hline \multirow[t]{2}{*}{ Migmatitic paragneiss } & \multirow[t]{2}{*}{ ES18 } & wt $\%$ & 0.86 & 65.73 & 15.80 & 1.03 & 1.98 & 5.56 & 4.83 & 1.86 & 0.84 & 0.11 & 0.58 \\
\hline & & $\mathrm{mol} \%$ & 3.09 & 70.84 & 10.04 & 1.09 & 3.18 & 5.48 & 3.32 & 1.94 & 0.68 & 0.10 & 0.24 \\
\hline
\end{tabular}

$\mathrm{wt} \%$ is the original measured composition, mol\% is the modelled composition (see Appendix in ESM)

\section{Results}

\section{U-Pb SHRIMP dating}

Magmatic monazite and zircon grains were targeted in felsic volcanic rock (RR72), from the westernmost area of the inlier, and three samples (RR71, RR77, ES19) of felsic peraluminous granites along an east-west transect across the inlier (Fig. 1).

\section{Zircon}

Zircon grains from all samples are euhedral to subhedral and range in size from 20 to $>100 \mu \mathrm{m}$. Twenty-two analyses were carried out on twenty zircon grains from RR72. Two concordant inherited core dates of $1624 \pm 14 \mathrm{Ma}$ and $1644 \pm 22 \mathrm{Ma}$ (in blue in Fig. 3a) were excluded from the average mean calculation (in red in Fig. 3a). 20 concordant analyses $(<10 \%$ discordance $)$ yield a single populationweighted mean ${ }^{207} \mathrm{~Pb} /{ }^{206} \mathrm{~Pb}$ age of $1550 \pm 7 \mathrm{Ma}(95 \%$ c.l., $n=20 ; \operatorname{MSWD}=1.13$; probability $=0.31$; Fig. $3 \mathrm{a}$ ). For the megacrystic Olsen Granite (RR71), two concordant inherited core dates of $1657 \pm 16 \mathrm{Ma}$ and $1648 \pm 13 \mathrm{Ma}$ (in blue in Fig. 3b) were excluded from the average mean calculation (in red in Fig. 3b) and a single population-weighted mean ${ }^{207} \mathrm{~Pb} /{ }^{206} \mathrm{~Pb}$ age of $1550 \pm 6 \mathrm{Ma}$ (95\% c.l., $n=19$; MSWD $=0.55$; probability $=0.94$; Fig. $3 \mathrm{~b}$ ) was calculated In the central domain, zircon analyses from the Goldsmiths Granite sample (RR77) yielded a single population-weighted mean ${ }^{207} \mathrm{~Pb} /{ }^{206} \mathrm{~Pb}$ age of $1551 \pm 7 \mathrm{Ma}(95 \%$ c.l., $n=21$; $\mathrm{MSWD}=0.80 ;$ probability $=0.71 ;$ Fig. $3 \mathrm{c})$. The leucocratic layer from the eastern domain (ES19) yielded a single population-weighted mean ${ }^{207} \mathrm{~Pb} /{ }^{206} \mathrm{~Pb}$ age of $1554 \pm 10 \mathrm{Ma}(95 \%$ c.l., $n=21$; MSWD $=1.8$; probability $=0.02$; Fig. $3 \mathrm{~d}$ ). Inherited cores were found in all the analysed samples during a previous LA-SS-ICPMS session (for collection of trace element data from zircon), but they were mostly avoided during the SHRIMP session. Occasional inherited core dates (in blue in Fig. 3a, b) are listed in the Electronic supplementary material Table $\mathrm{S} 3$ but were excluded from the mean age calculations.

\section{Monazite}

Monazite grains are scarce in sample RR72, but abundant in samples RR71, RR77 and ES19. Monazite crystals from all samples are mostly $10-60 \mu \mathrm{m}$, but can be as large as $150 \mu \mathrm{m}$. They are anhedral, or rounded to subhedral in shape, with irregular margins commonly replaced by apatite (Appendix Fig. S2 in ESM). The volcanic rocks from the western domain have concordant ages ranging between

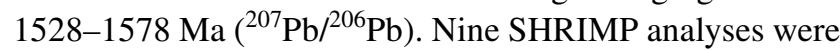
acquired from monazite grains. Eight are $<10 \%$ discordant and have low common $\mathrm{Pb}$. One analysis is $>10 \%$ discordant and was discarded. The remaining 8 concordant ( $<10 \%$ discordance) analyses yield a single populationweighted mean ${ }^{207} \mathrm{~Pb} /{ }^{206} \mathrm{~Pb}$ age of $1548 \pm 18 \mathrm{Ma}(95 \%$ c.1., $n=8 ; \mathrm{MSWD}=0.50$, probability $=0.83$; Fig. 3e). For the Olsen Granite (RR71), all the analyses have $<10 \%$ discordance and yielded a single population-weighted mean ${ }^{207} \mathrm{~Pb} /{ }^{206} \mathrm{~Pb}$ date of $1555 \pm 5 \mathrm{Ma}(95 \%$ c.l., $n=23$; MSWD $=0.68$; probability $=0.86$; Fig. $3 \mathrm{f}$ ), which is consistent with the weighted mean ${ }^{207} \mathrm{~Pb} /{ }^{206} \mathrm{~Pb}$ zircon crystallisation for the same sample. In the central domain, 15 monazite grains of the foliated Goldsmiths Granite (RR77) were analysed. Four grains with $>10 \%$ discordancy were discarded and one concordant analysis was rejected as a young outlier (Fig. 3g). The seventeen remaining concordant yielded a single population-weighted mean ${ }^{207} \mathrm{~Pb} /{ }^{206} \mathrm{~Pb}$ age of $1555 \pm 5 \mathrm{Ma}(95 \%$ c.1., $n=17$; MSWD $=1.08$; probability $=0.37$; Fig. $3 \mathrm{~g}$ ). For the leucocratic layer from the eastern domain, from a total of eighteen analyses on eight grains, one analysis was discarded as a concordant outlier and another two analyses were disregarded due to poor placement of the spots. The remaining 15 analyses yielded a single population-weighted mean ${ }^{207} \mathrm{~Pb} /{ }^{206} \mathrm{~Pb}$ age of $1555 \pm 3 \mathrm{Ma}$ (95\% c.l., $n=15$; MSWD $=1.3$; probability $=0.22$; Fig. $3 \mathrm{~h}$ ). This age is consistent with the weighted mean ${ }^{207} \mathrm{~Pb} /{ }^{206} \mathrm{~Pb}$ zircon crystallisation age for the same sample. 


\section{Trace elements in zircon and monazite}

\section{Zircon}

The Ti content in the analysed zircon rarely exceeds 20-30 ppm. Zircon trace elements are enriched in heavyREE (HREE) relative to the light REE (LREE) (Appendix Fig. S3a in ESM). A significant negative Eu anomaly suggests crystallisation of plagioclase during zircon growth. A progressive increase in HREE from $\mathrm{Gd}_{\mathrm{N}}$ to $\mathrm{Lu}_{\mathrm{N}}$ is characteristic of igneous zircon crystallising in the absence of garnet (Hoskin and Schaltegger 2003; Rubatto 2002).

\section{Monazite}

Monazite REE patterns are relatively consistent throughout all the samples (Appendix Fig. S3b in ESM). However, some variations are noted. Significant negative Eu anomalies reflect feldspar crystallisation in the melt during monazite growth. On the other hand, a shallow negative slope for the HREE is recorded by all the analysed monazite.

\section{Bulk-rock geochemistry}

The GTI granites and volcanic rocks have a silica range of 66-77 wt\% (Fig. 4a). Most major elements show negative correlation with silica, including $\mathrm{Al}_{2} \mathrm{O}_{3}, \mathrm{FeO}, \mathrm{MgO}$, and $\mathrm{CaO}$ (Fig. $4 \mathrm{e}-\mathrm{h}$ ). The alkali elements $\mathrm{Na}_{2} \mathrm{O}$ and $\mathrm{K}_{2} \mathrm{O}$ are more variable (Fig. $4 \mathrm{a}-\mathrm{d}$ ). The Einasleigh geochemical data (Electronic supplementary material Table S5) have slightly lower $\mathrm{Na}_{2} \mathrm{O}+\mathrm{K}_{2} \mathrm{O}$ values (5.2-5.7 wt\%) relative to those recorded by the other granitic samples (6.2-9.0 wt\%). The total alkali content of the Einasleigh leucosomes is particularly low (Fig. 4a), which may reflect melt loss during melt segregation during crystallisation or biotite replacement by epidote and chlorite (Pourteau et al. 2020).

The aluminium saturation index (ASI) diagram (Fig. 4b), shows a sublinear distribution for all felsic rocks. In most of the major oxide plots, the clusters defined by the western and central domain granites overlap with the eastern domain samples, but the latter follow slightly different trends. For example, the eastern domain trends are subhorizontal for $\mathrm{Na}_{2} \mathrm{O}$ (Fig. 4d) and $\mathrm{K}_{2} \mathrm{O}$ (Fig. 4c), whereas the remaining samples have a subvertical trends. Contrasting trends are also evident for $\mathrm{CaO}, \mathrm{FeO}$ and $\mathrm{Zr}$ (Fig. 4f, g, i) relative to the main GTI trend. $\mathrm{CaO}$ content is higher in the megacrystic granites from the central domain than in samples from the western and eastern domains (Fig. 4f). Nevertheless, all rocks are peraluminous, with ASI $>1$. The $\mathrm{Zr}$ content also decreases with increasing $\mathrm{SiO}_{2}$, except for the eastern domain (Fig. 4i), suggesting general zircon saturation for the magmatic system (Chappell et al. 1998; Kemp et al. 2005). The Einasleigh leucocratic layers from the eastern domain and the Croydon volcanic rocks and associated granites from the western domain, generally show greater variations in $\mathrm{Zr}$ content than the central granites (Fig. 4i). The general cluster distribution of the studied samples (Fig. 4) suggests that they were all part of a coherent magmatic system, hereafter referred to as the GTI igneous complex. This is also consistent with all the samples having the same emplacement age.

\section{Zircon saturation temperature $\left(T_{\mathrm{zr}}\right)$}

All the analysed samples have whole-rock chemical compositions that fall in the range of $M<1.9$ (with $\mathrm{M}=((\mathrm{Na}+\mathrm{K}+2 \mathrm{Ca}) /(\mathrm{Al} * \mathrm{Si}))$ as constrained by the Boehnke et al. (2013) model. Within the range of 66-77 wt\% $\mathrm{SiO}_{2}$, the peraluminous granites and the felsic volcanic rocks yield maximum zircon saturation temperatures $\left(T_{\mathrm{zr}}\right)$ that do not exceed $\sim 86{ }^{\circ} \mathrm{C}$ (Fig. 5a; Electronic supplementary material Table S6 and S7). In particular, in the western domain samples from the Croydon volcanic rocks record an average $T_{\mathrm{zr}}$ of $\sim 808 \pm 32{ }^{\circ} \mathrm{C}$, similar to the western domain plutons (i.e., Esmeralda, Olsen and Macartney), which have an average $T_{\mathrm{zr}}$ of $\sim 778 \pm 41^{\circ} \mathrm{C}, \sim 811 \pm 32{ }^{\circ} \mathrm{C}$ and, $\sim 860 \pm 1{ }^{\circ} \mathrm{C}$ respectively. The $T_{\mathrm{zr}}$ for the Forsayth, Goldsmiths, and Delaney granites from the central domain results in lower averages of $\sim 720 \pm 22{ }^{\circ} \mathrm{C}, \sim 746 \pm 35^{\circ} \mathrm{C}$ and $732 \pm 12{ }^{\circ} \mathrm{C}$, respectively, than the magmatic intrusions in the western domain. The low- $T$ values recorded by the Digger Creek Granite from the central domain $\left(600-730{ }^{\circ} \mathrm{C}\right)$, likely reflect the dominant pegmatitic component defining this intrusion (e.g., Champion 1991), suggesting crystallisation extended into the subsolidus field. The leucocratic layers in the eastern domain yield $T_{\mathrm{zr}}$ of $\sim 796 \pm 45^{\circ} \mathrm{C}$. The magmatic temperature estimates for all the granites are compared to those obtained for the metamorphic host rocks by phase equilibrium modelling, which recorded $\sim 550 \pm 60{ }^{\circ} \mathrm{C}, \sim 640 \pm 40{ }^{\circ} \mathrm{C}$ , $750 \pm 20^{\circ} \mathrm{C}$, in the western, central, and eastern domains, respectively (Volante et al. 2020a). Maximum granite $T_{\mathrm{zr}}$ values are slightly higher than the estimated temperature from the surrounding metamorphic rocks in the central and eastern domains. In contrast, in the western domain, the granite $T_{\mathrm{zr}}$ values were significantly hotter than the lowgrade phyllitic host rocks (Fig. 5a). The highest magmatic temperatures from the western domain $\left(780-860^{\circ} \mathrm{C}\right)$ yield an average temperature of $\sim 795 \pm 41{ }^{\circ} \mathrm{C}$ for all the volcanic and subvolcanic samples. In the eastern domain, the highest magmatic temperatures are $750-850{ }^{\circ} \mathrm{C}$, whereas leucocratic layers in migmatites yielded a $T_{\mathrm{zr}}$ average of $\sim 796 \pm 45^{\circ} \mathrm{C}$. By contrast, temperatures for each sample from the central domain range from 700 to $800{ }^{\circ} \mathrm{C}$, with a mean value of $\sim 735 \pm 30{ }^{\circ} \mathrm{C}$. 

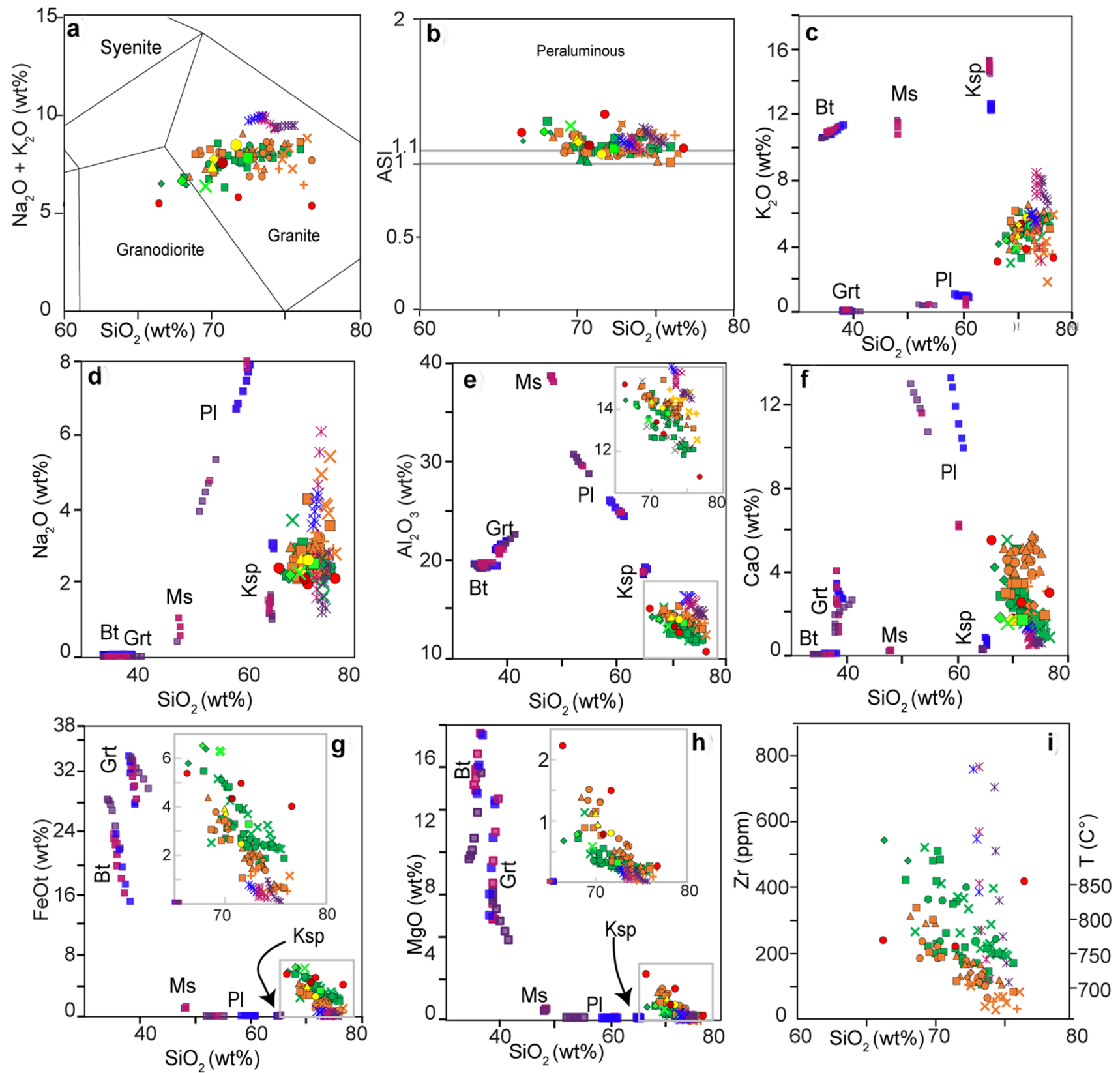

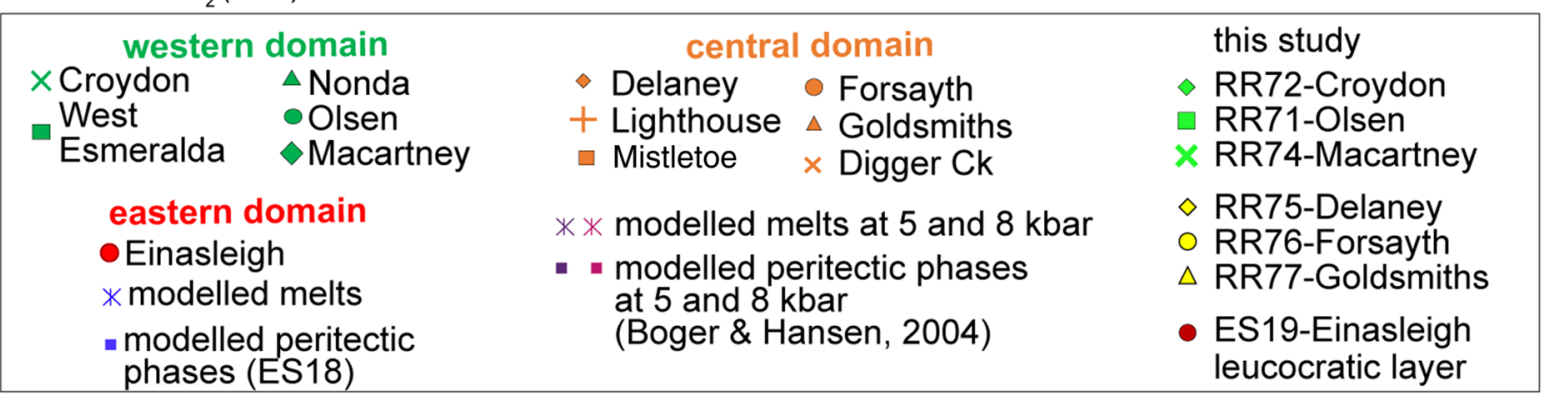

Fig. 4 Major and trace element $(\mathrm{Zr})$ classification of c. $1550 \mathrm{Ma}$ magmatic rocks from the GTI. a $\mathrm{Na}_{2} \mathrm{O}+\mathrm{K}_{2} \mathrm{O}$ vs $\mathrm{SiO}_{2}$. b $\mathrm{ASI}_{\text {vs }} \mathrm{SiO}_{2}$. c $\mathrm{K}_{2} \mathrm{O}$ vs $\mathrm{SiO}_{2}$. d $\mathrm{Na}_{2} \mathrm{O}$ vs $\mathrm{SiO}_{2}$. e $\mathrm{Al}_{2} \mathrm{O}_{3}$ vs $\mathrm{SiO}_{2}$. f $\mathrm{CaO}$ vs $\mathrm{SiO}_{2}$. $\mathbf{g} \mathrm{FeOt}$ vs $\mathrm{SiO}_{2}$. h $\mathrm{MgO}$ vs $\mathrm{SiO}_{2}$. i $\mathrm{Zr}$ vs $\mathrm{SiO}_{2}$ 

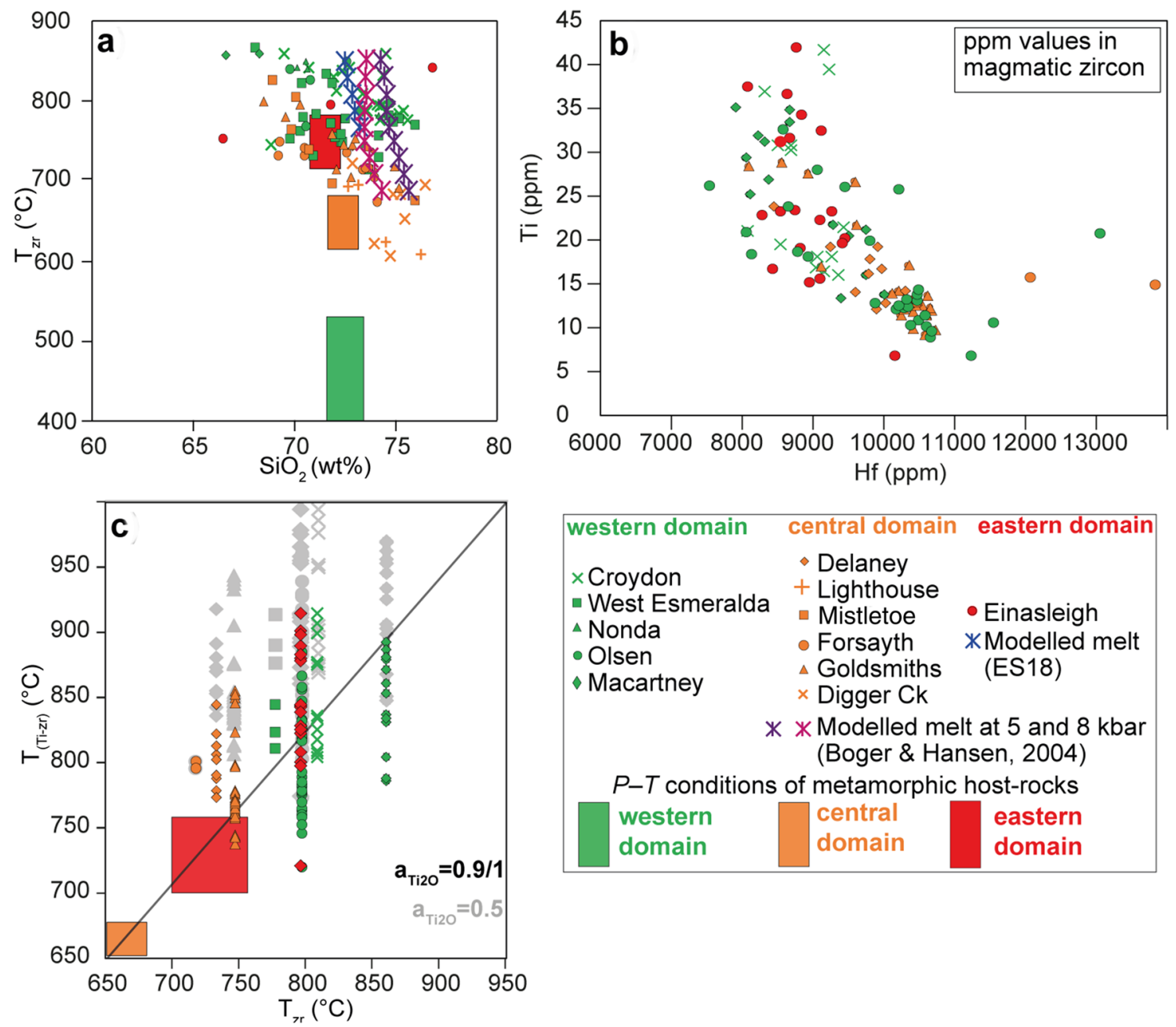

\begin{tabular}{|c|c|}
\hline western domain & central domain eastern domain \\
\hline $\begin{array}{l}\times \text { Croydon } \\
\text { - West Esmeralda } \\
\Delta \text { Nonda } \\
\text { - Olsen } \\
\text { - Macartney }\end{array}$ & $\begin{array}{l}\text { Delaney } \\
+ \text { Lighthouse } \\
\text { Mistletoe } \\
\text { - Forsayth } \\
\text { \& Goldsmiths } \\
\times \text { Digger Ck }\end{array}$ \\
\hline & $\begin{array}{l}* \text { Modelled melt at } 5 \text { and } 8 \text { kbar } \\
\text { (Boger \& Hansen, 2004) }\end{array}$ \\
\hline$P-T$ conditions & of metamorphic host-rocks \\
\hline $\begin{array}{l}\text { western } \\
\text { domain }\end{array}$ & $\begin{array}{l}\text { eastern } \\
\text { domain }\end{array}$ \\
\hline
\end{tabular}

Fig. 5 a Zircon saturation temperature values calculated using Boehnke et al. (2013) vs $\mathrm{SiO}_{2}$ (wt\%). b In-situ zircon Ti concentration (ppm) vs Hf concentration (ppm). c Comparison between Ti-inzircon temperatures (Ferry and Watson 2007; Watson et al. 2006) and

\section{Ti-in-zircon thermometer $\left(T_{(\mathrm{Ti}-\mathrm{zr})}\right)$}

In-situ $\mathrm{Ti}$ and $\mathrm{Hf}$ determination in $c .1550 \mathrm{Ma}$ magmatic zircons for all the analysed samples show a negative correlation (Fig. 5b), consistent with increasing degrees of zircon fractionation, again suggesting zircon saturation in these magmas. Temperature estimates for granitic magmas crystallising zircon were obtained using the Ti-in-zircon thermometer $\left(T_{(\mathrm{Ti}-\mathrm{zr})}\right.$; Fig. 5c; Electronic supplementary material Table S6 and S7) of Ferry and Watson (2007) and Watson et al. (2006). Most peraluminous granitic rocks in the GTI contain a Ti-rich mineral phase, typically ilmenite and sometimes rutile (i.e. RR77 in Table S1), so that $a_{\mathrm{TiO} 2}$ estimates between 0.6 and 0.9 (i.e. for ilmenite-bearing granites) or 1 (i.e. for rutile-bearing granites) are considered reasonable (Hayden and Watson 2007). Thus, temperatures with both higher and lower Ti activity values zircon saturation temperatures (Boehnke et al. 2013). Ti-in-zircon temperatures were calculated for each pluton with $a_{\mathrm{TiO} 2}=0.9 / 1$ (see Ti-in-zircon thermometer $\left(T_{(\mathrm{Ti}-\mathrm{zr})}\right)$ ) and $a_{\mathrm{TiO} 2}=0.5$ (based on Schiller and Finger 2019)

were calculated. The higher $a_{\mathrm{TiO} 2}$ values yield temperatures that are $60-80{ }^{\circ} \mathrm{C}$ lower than those with $a_{\mathrm{TiO} 2}=0.6$ (Electronic supplementary material Table S6). Hence, considering the occurrence of at least one rutile-bearing granite in the central domain, $a_{\mathrm{TiO} 2}$ values of 0.9 (for ilmenite-bearing rutile) and 1 (for rutile-bearing granites) are more realistic and produce temperature estimates that are more consistent with the average zircon saturation temperature values obtained for the different granites. In particular, the Croydon volcanic rocks in the western domain record eruptive temperatures ranging between $806-914{ }^{\circ} \mathrm{C}$ with an average of $849 \pm 40{ }^{\circ} \mathrm{C}$. Similarly, $T_{\text {(Ti-zr) }}$ values for the co-magmatic Esmeralda Supersuite vary between $809-842{ }^{\circ} \mathrm{C}$ (i.e., CUG01), $785-892{ }^{\circ} \mathrm{C}$ (RR74), and $718-883{ }^{\circ} \mathrm{C}$ (RR71) with average temperature values for CUG01, RR74, RR71 of $824 \pm 17{ }^{\circ} \mathrm{C}$, $849 \pm 37{ }^{\circ} \mathrm{C}$, and $798 \pm 42{ }^{\circ} \mathrm{C}$, respectively. In the central 
domain, $T_{\text {(Ti-zr) }}$ for the Forsayth Granite sample (RR76) shows similar or lower values $\left(795-800{ }^{\circ} \mathrm{C}\right)$ than the temperatures registered by the granites in the western domain. The Goldsmiths (RR77) and the Delaney (RR75) plutons, also from the central domain, have similar or lower $T_{\text {(Ti-zr) }}$ (738-856 ${ }^{\circ} \mathrm{C}$ and $764-846{ }^{\circ} \mathrm{C}$ ) compared to the Forsayth Granite, with averages of $793 \pm 35^{\circ} \mathrm{C}$ and $805 \pm 22^{\circ} \mathrm{C}$, respectively. By contrast, the leucocratic layer in the eastern domain (i.e., ES19), with an average of $844 \pm 46^{\circ} \mathrm{C}$, records higher $T_{(\text {Ti-zr) }}$ values of $720-914{ }^{\circ} \mathrm{C}$ than the granites from the central domain (Fig. 5c).
Monazite saturation temperature $\left(T_{\mathrm{mz}}\right)$

Monazite saturation temperature $\left(T_{\mathrm{mz}} ;\right.$ Fig. 6$)$ requires a whole-rock water content input (Montel 1993). For this calculation, the amount of $\mathrm{H}_{2} \mathrm{O}$ available was initially assumed as the average of the LOI value determined from whole-rock analysis $\left(\sim 1.5 \mathrm{wt} \% \mathrm{H}_{2} \mathrm{O}\right)$ (Fig. 6a; Electronic supplementary material Table S5). Based on this assumption, $1.5 \mathrm{wt} \% \mathrm{H}_{2} \mathrm{O}$ was used as the initial value and $T_{\mathrm{mz}}$ calculations yield the following ranges: $700-850{ }^{\circ} \mathrm{C}\left(\sim 790 \pm 40{ }^{\circ} \mathrm{C}\right)$ for the volcanic and a
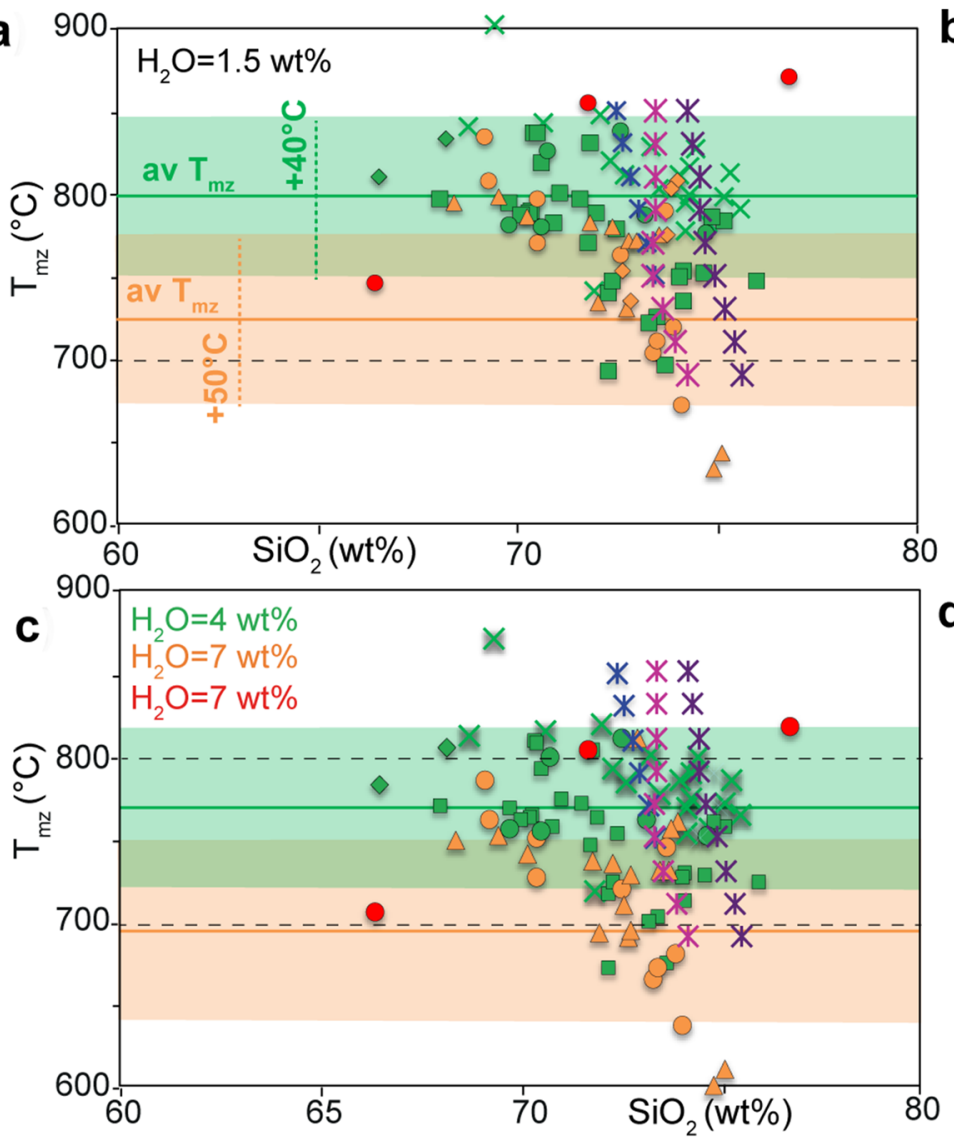

b

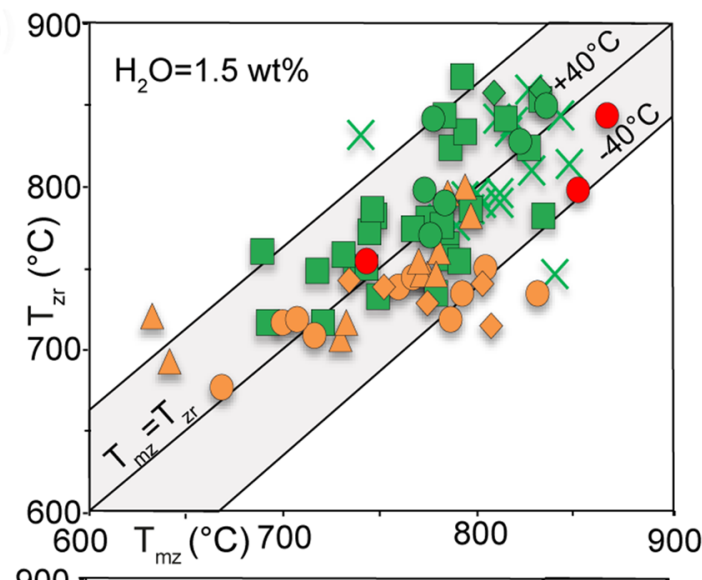

d

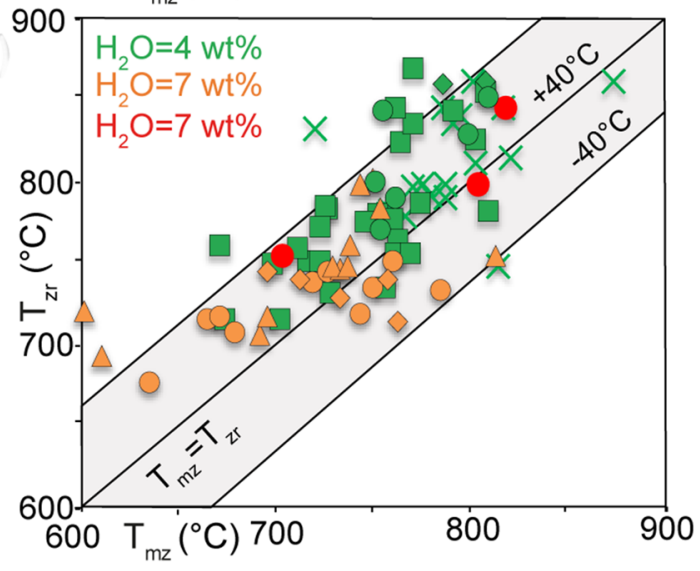

\begin{tabular}{|lll|}
\hline western domain & central domain & eastern domain \\
$\times$ Croydon & - Delaney & • Einasleigh \\
- West Esmeralda & * Mistletoe & *Modelled melt \\
$\begin{array}{l}\Delta \text { Nonda } \\
\text { - Olsen }\end{array}$ & - Forsayth & (ES18) \\
- Macartney & $\Delta$ Goldsmiths & $*$ Modelled melt at 5 and 8 kbar \\
& (Boger \& Hansen, 2004) \\
\hline
\end{tabular}

Fig. 6 a Plot of monazite saturation temperature (Montel 1993) vs $\mathrm{SiO}_{2}$ for peraluminous granites in the GTI using $1.5 \mathrm{wt} \% \mathrm{H}_{2} \mathrm{O}$. Average $T_{\mathrm{mz}}$ is represented by a continuous line, whereas StDev is highlighted by the coloured boxes (green and orange for the western and central domains, respectively). Black dashed lines mark the $700{ }^{\circ} \mathrm{C}$ and $800{ }^{\circ} \mathrm{C}$ temperature values. b Comparison between $T_{\mathrm{zr}}$ (Boehnke et al. 2013) and $T_{\mathrm{mz}}$ (Montel 1993) values using $\mathrm{H}_{2} \mathrm{O}$ content of 1.5 wt $\%$. c Re-calculated $T_{\mathrm{mz}}$ with $4 \mathrm{wt} \% \mathrm{H}_{2} \mathrm{O}$ for the upper-crustal level rocks (western domain) and with $7 \mathrm{wt} \% \mathrm{H}_{2} \mathrm{O}$ for the mid- to lowercrustal level rocks (central and eastern domain). d Comparison between $T_{z r}$ and $T_{m z}$ values with $\mathrm{H}_{2} \mathrm{O}$ contents of $4 \mathrm{wt} \%$ and $7 \mathrm{wt} \%$ 
subvolcanic rocks in the western domain, $650-800{ }^{\circ} \mathrm{C}$ $\left(\sim 735 \pm 65^{\circ} \mathrm{C}\right)$ for granitoids in the central domain, and $740-860{ }^{\circ} \mathrm{C}\left(\sim 822 \pm 66{ }^{\circ} \mathrm{C}\right)$ in the eastern domain. Samples from the Croydon volcanic rocks record an average $T_{\mathrm{mz}}$ of $\sim 812 \pm 33{ }^{\circ} \mathrm{C}$, similar to the western domain plutons (i.e., Esmeralda, Olsen and Macartney), which have an average $T_{\mathrm{mz}}$ of $\sim 770 \pm 38{ }^{\circ} \mathrm{C}, \sim 796 \pm 26{ }^{\circ} \mathrm{C}$ and, $\sim 821 \pm 17{ }^{\circ} \mathrm{C}$ respectively. The $T_{\mathrm{mz}}$ for the Forsayth, Goldsmiths, and Delaney granites from the central domain yield in lower average values $\left(\sim 755 \pm 52{ }^{\circ} \mathrm{C}, \sim 750 \pm 55^{\circ} \mathrm{C}\right.$ and $774 \pm 31{ }^{\circ} \mathrm{C}$, respectively) than the magmatic intrusions in the western domain. The leucocratic layers in the eastern domain yield $T_{\mathrm{mz}}$ of $\sim 822 \pm 66{ }^{\circ} \mathrm{C}$, comparable to the $T_{\mathrm{mz}}$ values recorded by the granitic and volcanic samples in the western domain. Thus, although partially overlapping, $T_{\mathrm{mz}}$ appears generally slightly higher than the respective $T_{\mathrm{zr}}-780-860{ }^{\circ} \mathrm{C}\left(\sim 795 \pm 40{ }^{\circ} \mathrm{C}\right), 700-800{ }^{\circ} \mathrm{C}$ $\left(\sim 720 \pm 50{ }^{\circ} \mathrm{C}\right)$, and $750-850{ }^{\circ} \mathrm{C}\left(\sim 795 \pm 45^{\circ} \mathrm{C}\right)$, respectively (Fig. 6b; see also Electronic supplementary material Table S6). After considering the $P-T$ conditions at which the GTI granites were emplaced at different crustal levels (see discussion below), the $\mathrm{H}_{2} \mathrm{O}$ content for the $T_{\mathrm{mz}}$ calculations was revised to $4 \mathrm{wt} \%$ and $6 \mathrm{wt} \%$ for the western granites and volcanic rocks and for the central and eastern granites, respectively. The revised $T_{\mathrm{mz}}$ results suggest lower temperatures $\left(\sim 700-730{ }^{\circ} \mathrm{C}\right.$ and $\left.\sim 770-800{ }^{\circ} \mathrm{C}\right)$ for the more hydrous mid-to lower-crustal melts. In contrast, less variation is shown by the $T_{\mathrm{mz}}$ values obtained for the more anhydrous upper-crustal granitic and volcanic rocks (see discussion below).

\section{Modelling results}

Phase-equilibrium diagrams were calculated to constrain the $P-T$ conditions at which the GTI igneous complex was formed. Two pressure conditions of 5 and $8 \mathrm{kbar}$ were chosen to evaluate the influence of depth on the primary melt composition (Fig. 7 and Appendix Fig. S4 in ESM). In particular, $5 \mathrm{kbar}$ (i.e., middle crustal level) is the pressure of the metamorphic peak recorded by the metasedimentary host rocks in the central domain, whereas 8 kbar (i.e., lowercrustal level) corresponds to the approximate pressure at which partial melting of the lower crust occurred in the eastern domain (Volante et al. 2020a). Those depths potentially represent the conditions of melt generation. The composition of the modelled melts produced at 5 and $8 \mathrm{kbar}$ are then compared with the composition of the GTI batholiths in the central and eastern domains (Fig. 4).

\section{$P-T$ pseudosections}

The $P-T$ pseudosections for the possible GTI granites metasedimentary source-rock candidates are shown in Fig. 7 and Appendix Fig. S4 in ESM. The stability field of the

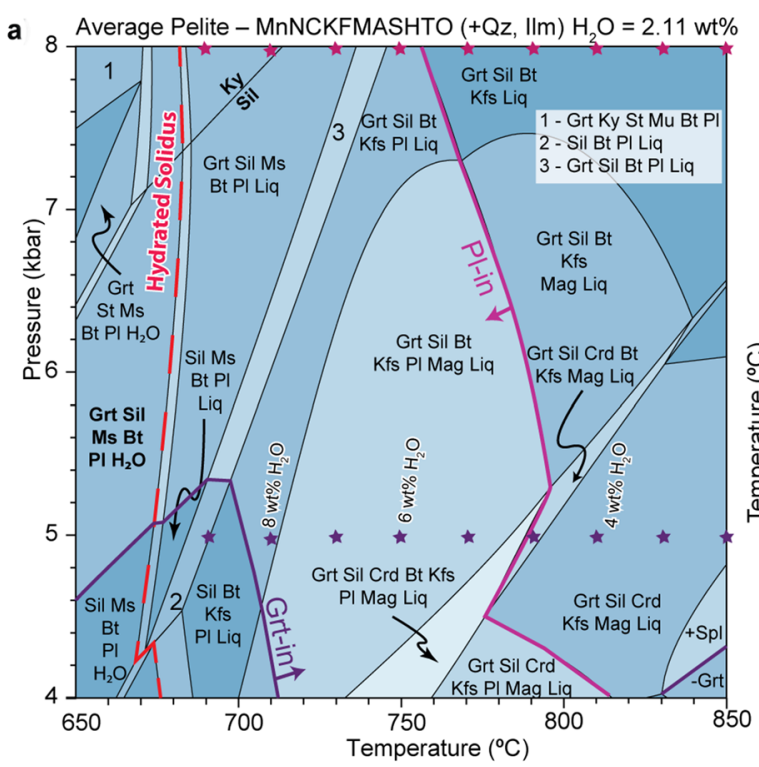

Fig. 7 a $P-T$ and b $T-X$ pseudosections for the MAMC after Boger and Hansen (2004) (see also Table 1). a The stars indicate the $P-T$ conditions at which the modelled melt compositions were calculated (purple $=5 \mathrm{kbar}-$ i.e., middle crust); pink $=8 \mathrm{kbar}$-i.e., deep crust). Water content within the modelled melt compositions is identified by the text labels (see also Electronic supplementary material Table S4). b $T-X_{\mathrm{H} 2 \mathrm{O}}$ pseudosection with $X=0$ at 0.51 wt $\% \mathrm{H}_{2} \mathrm{O}$ and $X=1$ at

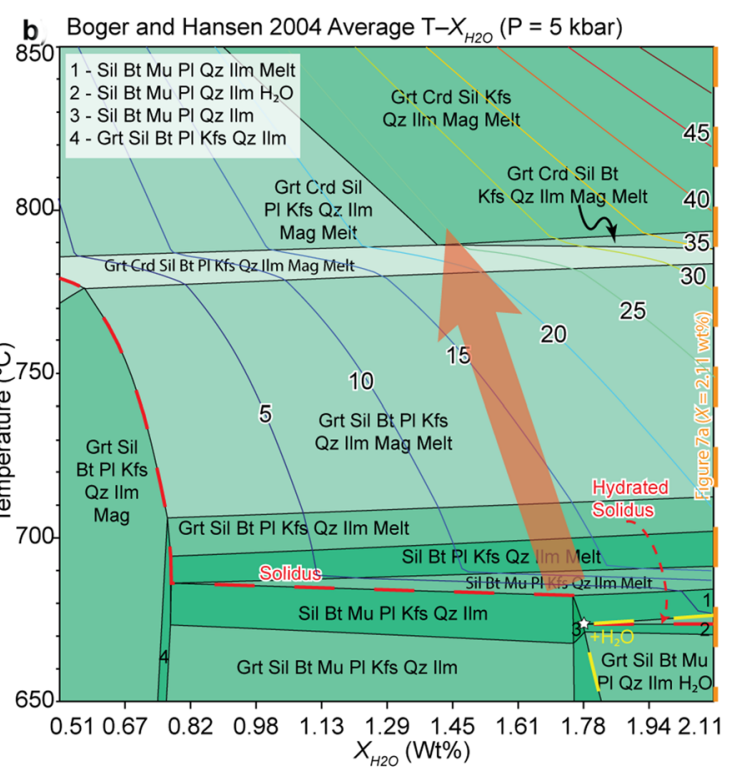

$2.11 \mathrm{wt} \% \mathrm{H}_{2} \mathrm{O}$. The coloured contours represent the melt proportion in mol \%. The composition used for $\mathbf{a}$ is indicated by a dashed orange line. The solidus is indicated by the dashed red line. The dashed yellow line bound the fields were $\mathrm{H}_{2} \mathrm{O}$ is present as a free phase. The thick red arrow shows the trajectory of water loss from the sourcerock if melt aliquots are considered to be progressively removed as temperature increases 
peak metamorphic assemblages in the central and eastern domains (represented in bold font in Fig. 7a and Appendix Fig. S4 in ESM) were recently constrained at $600-670{ }^{\circ} \mathrm{C}$, 4-6 kbar and at $\sim 750{ }^{\circ} \mathrm{C}, \sim 8 \mathrm{kbar}$, respectively (Volante et al. 2020a). The average metapelitic composition for the central domain (i.e. MAMC) was modelled with $\mathrm{H}_{2} \mathrm{O}$ content of $2.11 \mathrm{wt} \%$ (Table 1), which generates excess water in the system. This is shown by the presence of water in the subsolidus assemblages at $670{ }^{\circ} \mathrm{C}$ (Fig. 7a). The investigation involves to calculate $\mathrm{H}_{2} \mathrm{O}$ content in the melts, and melt volumes, which are too high. This is illustrated in Fig. 7a, which shows the impact of additional water on melt volumes. Paragneiss ES18 was modelled with all LOI assumed as $\mathrm{H}_{2} \mathrm{O}\left(\mathrm{H}_{2} \mathrm{O}=0.86 \mathrm{wt} \%\right.$; see also Table 1$)$.

The hydrated solidus is near isothermal, ranging from $\sim 667{ }^{\circ} \mathrm{C}$ at $\sim 4 \mathrm{kbar}$ to $682{ }^{\circ} \mathrm{C}$ at $\sim 8 \mathrm{kbar}$ (Fig. 7a), but with a distinct kink between $4-5 \mathrm{kbar}$, associated with muscovite breakdown at higher $P$. Quartz, sillimanite (or kyanite at higher $P$ ) and ilmenite are stable in all melts, biotite persists up to higher $T$ at higher $P\left(>850{ }^{\circ} \mathrm{C}\right.$ above $\left.\sim 5 \mathrm{kbar}\right)$, and $\mathrm{K}$-feldspar is stable up to high temperatures $\left(>850^{\circ} \mathrm{C}\right)$ across a broader $P$ range. Garnet is only stable above $4 \mathrm{kbar}$ at low $T\left(<710{ }^{\circ} \mathrm{C}\right)$, but its $P$ range increases markedly at higher $T$.

At 5 kbar and $\sim 680{ }^{\circ} \mathrm{C}$ muscovite breakdown and dissolution of $\mathrm{H}_{2} \mathrm{O}$ are the main melt-forming reaction, generating melts with $>7 \mathrm{wt} \% \mathrm{H}_{2} \mathrm{O}$, whereas at $\sim 785^{\circ} \mathrm{C}$, biotite breakdown is an additional key source of $\mathrm{H}_{2} \mathrm{O}$ into the system (Fig. 7a). The amount of $\mathrm{H}_{2} \mathrm{O}$ present within the liquid progressively decreases with increasing $T$ as more melt is produced. In contrast, at $8 \mathrm{kbar}$ muscovite breakdown begins at $\sim 735^{\circ} \mathrm{C}$, whereas biotite is stable up to higher temperatures $\left(>850{ }^{\circ} \mathrm{C}\right)$. Therefore, at this pressure, a greater amount of melt is produced only as higher temperatures are reached, provided no water is added to the system.

\section{Modelled melts and peritectic mineral phases compared to the GTI igneous complex}

Modelled primary melt and solid mineral phase compositions extracted from the $P-T$ pseudosections (Fig. 7a and Appendix Fig. S4 in ESM) are presented in the Electronic supplementary material Table S4 and plotted in Fig. 4, where they are compared to the compositions of the GTI granite samples.

Partial melting of the average Georgetown metapelite produces slightly more silicic melts at $5 \mathrm{kbar}$ than at $8 \mathrm{kbar}$ $\left(\mathrm{SiO}_{2}=74-76 \mathrm{wt} \%\right.$ vs 73-74 wt\%) (Fig. 4a). In both cases, higher mafic melt compositions of each array correspond to higher $T$ melting conditions. These primary melts coincide with the high silica end of the GTI granite spectrum and overlap in ASI ratios (Fig. 4b) and $\mathrm{MgO}$ contents (Fig. 4h). The alkali contents are generally higher (Fig. 4a, c, d) and
$\mathrm{CaO}$ lower (Fig. 4f) for the predicted melts than the granites, suggesting an excess of alkali feldspar component relative to plagioclase. Elevated alkali contents occurs typically under relatively anhydrous conditions, where biotite and muscovite breakdown release their orthoclase component, and plagioclase remains as a residual phase. Indeed, $\mathrm{CaO}$ variation supports the presence of residual plagioclase because the GTI granites lie on a tie-line between modelled melts and residual plagioclase (Fig. 4f). $\mathrm{Na}_{2} \mathrm{O}$ and $\mathrm{Al}_{2} \mathrm{O}_{3}$ variation vs $\mathrm{SiO}_{2}$ (Fig. 4d, e) also require residual plagioclase, but with a subordinate low- $\mathrm{Al}_{2} \mathrm{O}_{3}$ trend toward residual biotite or garnet (Fig. 4e). The influence of biotite and/or garnet retention in the melts is best shown by the western domain granites and the eastern domain data in Fig. $4 \mathrm{~g}$ and h, with all the GTI granites projecting from melt compositions toward both garnet and biotite for $\mathrm{FeO}$ and $\mathrm{MgO}$. Additionally, the green (western domain) symbols plot on the top of the array in Fig. 4g, where garnet is above biotite, and at the bottom of the array in Fig. $4 \mathrm{~h}$, where garnet plots below biotite. This demonstrates a more substantial influence of restitic garnet retention in the western domain granites, relative to the easter domain (see discussion).

Melting of metapelitic rocks (ES18) in the eastern domain produces primary melts with ASI values of 1.11-1.17 (Fig. 4b), higher $\mathrm{Na}_{2} \mathrm{O}$ (Fig. 4a, d), and similar $\mathrm{CaO}$ (Fig. 4f), when compared to the melts produced in the central domain at a similar pressure. In contrast to the western domain granites, the modelled melts for the eastern domain project more toward biotite than garnet, as shown by a flatter $\mathrm{FeO}$ trend and a steeper $\mathrm{MgO}$ trend in Fig. $4 \mathrm{~g}$ and h. Between the modelled melts, the compositions produced in the central domain at 5 kbar better reproduce and closely overlap the observed compositional array of the GTI granites (Fig. 4). This suggests that most GTI granites were produced at $P$ lower than $8 \mathrm{kbar}$.

Temperatures for each modelled melt composition (at 5 and $8 \mathrm{kbar}$ ) were used to calculate the $\mathrm{Zr}$ contents for the modelled melts by applying the Boehnke et al. (2013) model (Electronic supplementary material Table S6). The results show that the $\mathrm{Zr}$ content of melts produced at low temperatures $\left(690-750{ }^{\circ} \mathrm{C}\right)$ reflects the $\mathrm{Zr}$ concentrations (ppm) observed for the granites in the central domain (100-350 ppm, Fig. 4f). However, the melts modelled at temperatures $>750{ }^{\circ} \mathrm{C}$ show a $\mathrm{Zr}$ content $>300 \mathrm{ppm}$, peaking at $\sim 800 \mathrm{ppm}$ and resembling the higher $\mathrm{Zr}$ values recorded by one Einasleigh leucocratic layers in the eastern domain, and more generally with the Croydon volcanic rocks and associated granites in the western domain.

\section{$T-X$ pseudosection of the average metapelite (MAMC)}

In light of the results obtained from the $P-T$ pseudosections (Fig. 7a), a $T-X_{\mathrm{H} 2 \mathrm{O}}$ diagram of the MAMC was 
calculated at 5 kbar (i.e., middle crustal level) over a temperature range of $650-850{ }^{\circ} \mathrm{C}$, to determine the minimum saturation point (Webb et al. 2015) and how the variation of water influences melt volumes at suprasolidus conditions (Fig. 7b). For this purpose, the $T-X_{\mathrm{H} 2 \mathrm{O}}$ diagram was calculated between $X_{\mathrm{H} 2 \mathrm{O}}=0.51 \mathrm{wt} \%$ and $X_{\mathrm{H} 2 \mathrm{O}}=2.11 \mathrm{wt} \%$ (Table 1), to determine the maximum amount of structurally-bound water contained within the subsolidus assemblage below the solidus (Fig. 7b). This value is $1.78 \mathrm{wt} \%$ $\mathrm{H}_{2} \mathrm{O}$ and is the Minimum Saturation Point (MSP) (Webb et al. 2015). The MSP which is somewhat lower than the conservative subsolidus $\mathrm{H}_{2} \mathrm{O}$ (i.e., $\mathrm{CSW}$ ), which is represented by the vertical orange dashed line at $X_{\mathrm{H} 2 \mathrm{O}}=2.11$ wt\% (Fig. 7b). The isopleths represent the melt proportions if the source-rock contained the average amount water that was analysed, but this value is unrealistic.

An inflection in the solidus curve at low $\mathrm{H}_{2} \mathrm{O}$ contents $\left(<0.78 \mathrm{wt} \% \mathrm{H}_{2} \mathrm{O}\right)$ correspond to changes in modal mineralogy. Between $X_{\mathrm{H} 2 \mathrm{O}}=0.78 \mathrm{wt} \%$ and $X_{\mathrm{H} 2 \mathrm{O}}=2.11$ $\mathrm{wt} \%$ the solidus is subhorizontal, and therefore near isothermal, ranging from 673 to $688{ }^{\circ} \mathrm{C}$, but with a distinct step at $X_{\mathrm{H} 2 \mathrm{O}}=\sim 1.75 \mathrm{wt} \%$ associated with the transition from the hydrated solidus as all subsolidus water is lost from the rock assemblage and melting begins (i.e. MSP). Melt productivity of melt increases with temperature as water is dissolved into the magma (Johnson et al. 2008), as shown directly by the correlation of $\mathrm{H}_{2} \mathrm{O}$ content and melt volumes (Fig. 7b). At lower $T\left(<680^{\circ} \mathrm{C}\right)$, under near solidus conditions, water saturated melts exist within a narrow field (dashed yellow line in Fig. 7b). At higher $T$, free $\mathrm{H}_{2} \mathrm{O}$ is rapidly dissolved into the melt, together with that produced by breakdown of muscovite $\left(\sim 690^{\circ} \mathrm{C}\right)$, and the melt fraction rapidly increases with increased temperature-evident from the subhorizontal melt isopleths (Fig. 7b). Above $690^{\circ} \mathrm{C}$, the melt fraction isopleths have a steeper slope slope once muscovite is consumed, reflecting ongoing breakdown of biotite ( \pm plagioclase) as $T$ and $\mathrm{H}_{2} \mathrm{O}$ content. At $\sim 690{ }^{\circ} \mathrm{C}$, muscovite breakdown produces up to $\sim 10 \%$ of melt without the addition of water (at MSP). Above $\sim 690{ }^{\circ} \mathrm{C}$, increasing $T$ produces greater volumes of melt, reaching $\sim 15 \%$ at $710{ }^{\circ} \mathrm{C}$. However, with only $0.33 \mathrm{wt} \% \mathrm{H}_{2} \mathrm{O}$ added at the same temperature (i.e. total $X_{\mathrm{H} 2 \mathrm{O}} \sim 2.11 \mathrm{wt} \%$ ), $\sim 20 \%$ melt is produced. Similarly, assuming melt loss with increasing temperature, $20 \%$ melt production requires $X_{\mathrm{H} 2 \mathrm{O}} \sim 1.42 \mathrm{wt} \%$ in the source, and $T$ of $\sim 790{ }^{\circ} \mathrm{C}$ (thick red arrow in Fig. 7b). If the $\mathrm{H}_{2} \mathrm{O}$ content was increased to $\mathrm{X}_{\mathrm{H} 2 \mathrm{O}} \sim 2.11 \mathrm{wt} \%$ at $\sim 790{ }^{\circ} \mathrm{C}$, the amount of melt would be $30-35 \%$ (Fig. $7 \mathrm{~b}$ ). These calculations show the efficiency of magma production if water is added to the crust during melting under equilibrium conditions.

\section{Discussion}

\section{Zircon and monazite geochronology}

Regardless of the crustal levels at which the granitic magmas were emplaced (upper, middle or lower crust), zircon and monazite yielded similar crystallisation ages of c. $1555 \mathrm{Ma}$ (Fig. 3). This outcome indicates that the felsic extrusive and intrusive rocks of the GTI were part of a crustal-scale magmatic system, generated from $\sim 30 \mathrm{~km}$ ( $\sim 8 \mathrm{kbar})$ depth in the eastern domain, and emplaced throughout the crust (central domain), and erupted in the western domain.

\section{Zircon thermometry of the GTI S-type granites}

A commonly held view is that zircon saturation is not reached during the generation of granitic magmas until late in their crystallisation history. This view is generally held either because it is assumed that granites are the fractionated products of basaltic magmas (e.g., Siégel et al. 2018) or because granites are considered to have been produced by high- $T\left(\sim 850{ }^{\circ} \mathrm{C}\right)$ dehydration melting during the breakdown of hydrous minerals, particularly biotite and/or hornblende (e.g., Clemens et al. 2020 and reference therein). Some of the GTI granites appear to have formed at high- $T$, but others seem to have been generated at a lower temperature, probably $730-750{ }^{\circ} \mathrm{C}$, as discussed below. The major oxide variations presented in Fig. 4 support the presence of residual phases such as plagioclase, garnet, and biotite because the GTI granites lie on a tie-line between modelled melts and the residual minerals determined by phase equilibria modelling. This suggests that the GTI granites are mushes of a mixture of melt and residual crystals. Zircon is another restistic phase, as evidenced by the presence of zircon cores. The diagonal array of decreasing $\mathrm{Zr}$ with increasing $\mathrm{SiO}_{2}$ (Fig. 4i) is considered to reflect progressive segregation of restitic zircon from the low $T\left(\sim 680-750^{\circ} \mathrm{C}\right)$ crystal mush, along with other restitic minerals. The highly variable $\mathrm{Zr}$ contents for the eastern domain (red dots in Fig. 4i) can potentially be explained by enhanced retention in the melts (the high value) and selective retention in the source rock (the low value). Alternatively, the $\mathrm{Zr}$ variation suggests variable $T$, with the high- $\mathrm{Zr}$ values represented one melt increment generated at substantially hotter $T\left(\sim 850{ }^{\circ} \mathrm{C}\right)$, and the low-Zr values reflecting near solidus cooling. The best overlap of actual and modelled $\mathrm{Zr}$ content occurs at values $<300 \mathrm{ppm}$ (Fig. 4i), suggesting that most of the silicic melts of the GTI were produced at low temperature $\left(\sim 730-750{ }^{\circ} \mathrm{C}\right)$. Also, the modelled melts produced at 5 
kbar (i.e., middle crustal level) better reproduce the compositions of most GTI granitic rocks (Fig. 4). Nonetheless, the high- $\mathrm{Zr}$ content of the Croydon volcanic rocks in the west and the Einasleigh leucocratic layers in the east suggest that some of those melts were formed at higher temperatures (Fig. 5a).

However, $T_{\mathrm{zr}}$ values in the central domain cluster at $~ 730-750{ }^{\circ} \mathrm{C}$ over an extended silica range $(68-75 \mathrm{wt} \%$ $\mathrm{SiO}_{2}$ ), suggesting a slightly different magmatic process than high- $T$ melting. The $T_{\mathrm{zr}}$ values are close to the peak metamorphic temperatures of $\sim 750{ }^{\circ} \mathrm{C}$ recorded in the lowercrustal (8-9 kbar) eastern domain (Volante et al. 2020a), so it is possible that they formed in the deep crust and stalled in the middle crust (5-6 kbar) of the central domain. The modelled melt compositions overlap with the GTI array more completely for the high silica endmembers produced at $5 \mathrm{kbar}$ than at $8 \mathrm{kbar}$, but the difference is not significant (Fig. 4). It is notable that for both pressure conditions, the modelled melt compositions approach the natural (i.e., GTI) array at lower temperatures (Fig. 4i). Therefore, it is likely that the central domain granites were generated at relatively low $T\left(730-750^{\circ} \mathrm{C}\right)$, either in the middle or lower crust, from metasedimentary schists with compositions similar to the MACM (Boger and Hansen 2004), rose adiabatically, and did not migrate far from their source (Fig. 8). By contrast, extrusive and intrusive rocks of the western, upper-crustal domain, with temperatures of $>800^{\circ} \mathrm{C}$, were emplaced into much cooler, low-grade phyllites.

Recent studies have suggested that a Ti activity $\left(a_{\mathrm{TiO} 2}\right)$ range of $0.1-0.5$ should be used to determine magmatic

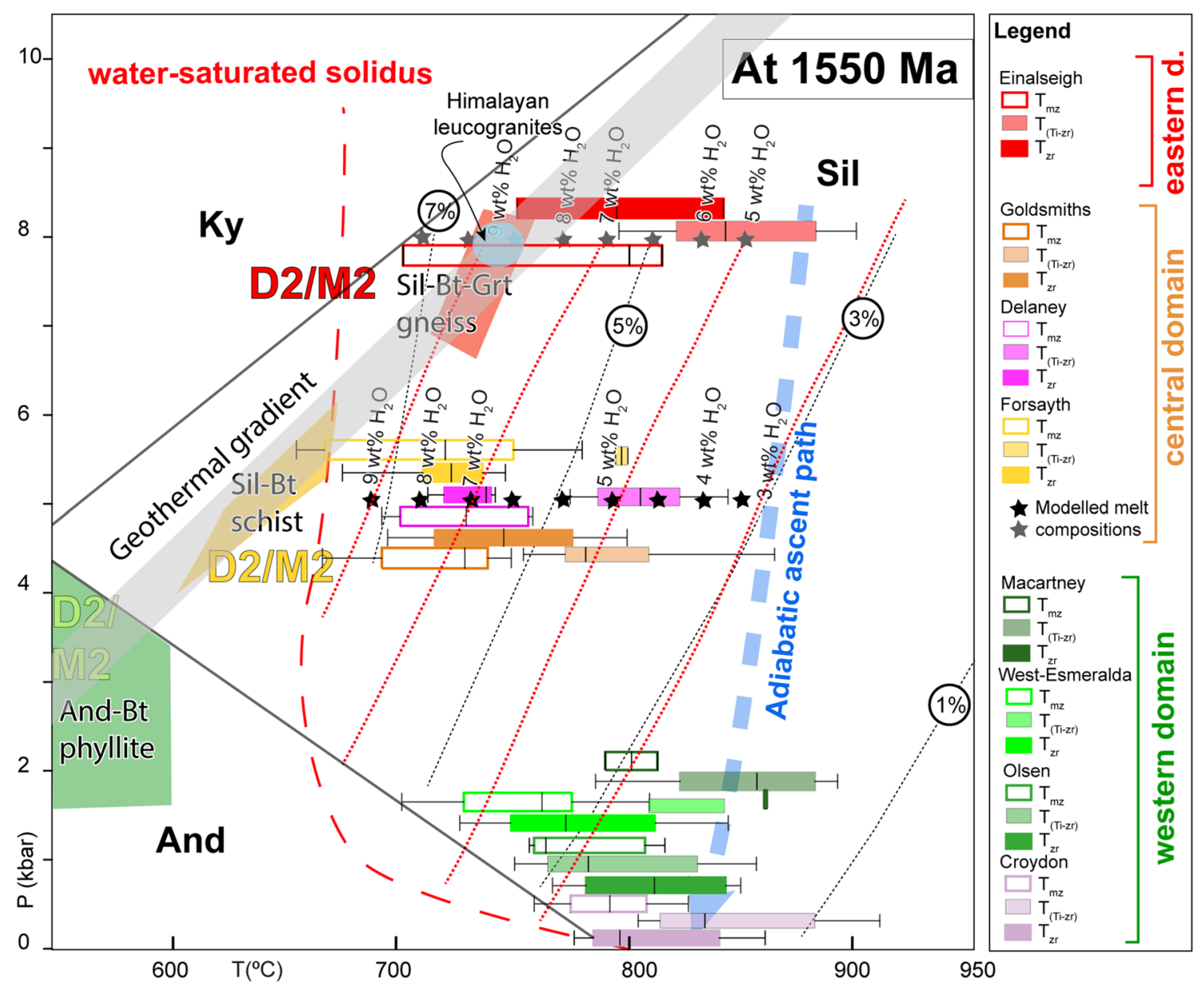

Fig. $8 P-T-X_{\mathrm{H} 2 \mathrm{O}}$ grid showing the estimated temperatures for all the analysed samples using three independent thermometers $\left(T_{(\mathrm{Ti}-\mathrm{zr})}, T_{\mathrm{zr}}\right.$ and $\left.T_{\mathrm{mz}}\right)$. The solidus was extracted from the calculated pseudosection for the MAMC. The liquidus curves for the minimum melt compositions at several $\mathrm{H}_{2} \mathrm{O}$ concentrations are taken from Holtz et al. (2001) (black dotted lines) and extrapolated from phase equilibria modelling (red dotted lines) using water value of $2.11 \mathrm{wt} \% \mathrm{H}_{2} \mathrm{O}$. The green, yellow, and red polygons on the left hand-side of the diagram represent the $P-T$ conditions estimated for the metamorphic host rocks (Volante et al. 2020a) at upper-, mid-, and lower-crustal levels. The black and grey stars indicate the representative $P-T$ conditions of the modelled melt compositions at $5 \mathrm{kbar}$ and $8 \mathrm{kbar}$, respectively. The light blue circle represents the $P-T$ conditions estimated for Himalayan leucogranites (Patiño Douce and Harris , 1998). The grey band reflect the inferred geothermal gradient of the GTI crust at c. $1550 \mathrm{Ma}$ 
temperatures in rutile-devoid, ilmenite-bearing S-type granites (Schiller and Finger 2019). To assess this suggestion, Ti-in-zircon $\left(T_{(\mathrm{Ti}-z r}\right)$ temperatures with both $a_{\mathrm{TiO} 2}=0.5$ and $a_{\mathrm{TiO} 2}=0.9$ (or $a_{\mathrm{TiO} 2}=1$ for RR77 Goldsmiths Granite) were plotted against $T_{z r}$ (Fig. 5c). Using $a_{\mathrm{TiO} 2}=0.5$, averages of $920 \pm 45{ }^{\circ} \mathrm{C}, 920 \pm 42{ }^{\circ} \mathrm{C}, 863 \pm 47{ }^{\circ} \mathrm{C}$, and $892 \pm 19{ }^{\circ} \mathrm{C}$ were obtained for the Croydon volcanic rocks, and the granites in the western domain (Macartney, Olsen, and West Esmeralda); $857 \pm 40{ }^{\circ} \mathrm{C}, 862 \pm 4{ }^{\circ} \mathrm{C}$, and $871 \pm 25^{\circ} \mathrm{C}$ were recorded by the granites in the central domain (Goldsmiths, Forsayth, and Delaney); and $915 \pm 52{ }^{\circ} \mathrm{C}$ was estimated for the leucocratic melts in the eastern domain. These results are consistently $60-80{ }^{\circ} \mathrm{C}$ higher than the temperatures obtained with $a_{\mathrm{TiO} 2}=0.9 / 1$ (Fig. $5 \mathrm{c}$ ). What is clear from these contrasting ranges for differing Ti activities is that the $T$ values at $a_{\mathrm{TiO} 2}=0.9 / 1$ are much closer to the $T_{\mathrm{zr}}$ values than those generated at $a_{\mathrm{TiO} 2}=0.5$ for the S-type granites of the GTI.

Moreover, if a $T_{\text {(Ti-zr) }}$ temperature constraint of $a_{\mathrm{TiO} 2}=0.5$ from Schiller and Finger (2019) is used, the metamorphic crust hosting the GTI igneous complex should have formed at $T>900{ }^{\circ} \mathrm{C}$, i.e., ultra-high-temperature (UHT) conditions (cf. Brown and Raith 1996; Sengupta et al. 1999). At these inferred temperatures, and assuming an average geothermal gradient of $\sim 30{ }^{\circ} \mathrm{C} / \mathrm{km}$ (Fig. 8), the Einasleigh migmatites in the eastern domain would need to have formed at pressures $>11 \mathrm{kbar}$, for which there is no evidence. Instead, the leucosomes are derived in situ at 8-9 kbar (Fig. 8), so the Schiller and Finger (2019)'s preference for using low $a_{\mathrm{TiO} 2}$ does not accord with this study. A titanium activity of $0.9 / 1$ is considered more plausible for determining $T_{(\mathrm{Ti}-\mathrm{zr})}$ temperatures for $<$ S-type granites, which better accords with $T_{\mathrm{zr}}$ temperatures (Fig. 5c) and with ilmenite saturation in the magmas over the entire $P-T$ range (Fig. 7a).

Nonetheless, a comparison of $T_{\mathrm{zr}}$ values with temperatures obtained within the individual GTI plutons using Ti-inzircon thermometry is important. The granite suites record $T_{\mathrm{zr}}$ values that are consistently within the lowest- $T$ range estimated by Ti-in-zircon thermometry. One way to explain this discrepancy is to consider that the temperature peaks recorded by the latter represent thermal spikes within the magma chamber, which were captured by zircon growth. Supporting evidence comes from the presence of mafic enclaves within many of the western and central domain plutons, which represent hotter mafic magmas that were infused, mingled, and dispersed through the mid-crustal magma chambers (e.g., Vernon 1984).

\section{$P-T-X_{\mathrm{H} 2 \mathrm{O}}$ conditions of granitic magmas}

The results of zircon and monazite thermometry are plotted along with the $P-T$ conditions recorded by the metamorphic host rocks of the GTI on a $P-T-X_{\mathrm{H} 2 \mathrm{O}}$ grid (Fig. 8). Petrographic observations and thermodynamic modelling results indicate that most granitic magmas in the central GTI were emplaced at $\sim 5 \mathrm{kbar}$ (see also Volante et al. 2020a). The average $\sim 790-800{ }^{\circ} \mathrm{C}$ magmatic temperature estimates of the melts, calculated $T_{\mathrm{zr}}$ and $T_{\mathrm{mz}}$ (Fig. 6a), are similar to estimated temperatures $\left(\sim 750{ }^{\circ} \mathrm{C}\right)$ for the host Einasleigh Metamorphics, consistent with the occurrence of leucocratic layers as residual leucosomes in these lower crustal, extensively melted migmatites. These temperature conditions are also consistent with the presence of restitic plagioclase in the melts, which only occurs at temperatures $<790{ }^{\circ} \mathrm{C}$ at $>5 \mathrm{kbar}$ (Fig. 7a). Thus, most of the GTI igneous complex appears to have been derived from and thermally equilibrated within, the middle (central domain) and deep crust (eastern domain). Therefore, we argue that the S-type granitic magmatism generated melts that did not migrate far from their source and accumulated near in situ, in the middle crust. By contrast, the volcanic rocks in the western domain, and their subvolcanic equivalents, record temperatures of $800-850{ }^{\circ} \mathrm{C}$, a range which is distinctly hotter than the midcrustal granitic rocks. In addition, the compositional trends for the western granites (Fig. 4g, h) suggest a stronger influence of restitic garnet retention within those granites, which is supported by the presence of garnet and is consistent with a lower-crustal source. Therefore, it seems likely that the Croydon volcanic rocks and the Esmeralda sub-volcanic intrusive rocks were derived from the lower crust, under $P-T$ conditions similar to those recorded by the Einasleigh Metamorphics (Fig. 8).

Based on these considerations, we infer that many of the granites of the GTI igneous complex have equilibrated in the middle- and deep crust and that the water content of these magmas can be estimated by comparing the liquidus curves from Holtz et al. (2001) with the water content obtained from phase equilibria modelling (black vs red dashed lines in Fig. 8). The two arrays of liquidus curves have similar slopes at $\leq 5 \mathrm{wt} \% \mathrm{H}_{2} \mathrm{O}$, although the Holtz et al. (2001) curves are steeper at higher $\mathrm{H}_{2} \mathrm{O}$ content $\left(>7 \mathrm{wt} \% \mathrm{H}_{2} \mathrm{O}\right)$. The most significant difference is in the absolute values of the liquidus curves, with the Holtz et al. (2001) values consistently lower under relatively hydrous conditions. The higher modelled $\mathrm{H}_{2} \mathrm{O}$ contents at $>3 \mathrm{wt} \% \mathrm{H}_{2} \mathrm{O}$ (Fig. 8) probably reflects the higher-water content used for the modelled source-rock (2.11 wt $\% \mathrm{H}_{2} \mathrm{O}$ ), rather than estimates based on the MSP value $\left(1.78 \mathrm{wt} \% \mathrm{H}_{2} \mathrm{O}\right)$. That the $\mathrm{H}_{2} \mathrm{O}$ values are in excess is shown in Fig. 7b, where $\mathrm{H}_{2} \mathrm{O}$ is present as a free phase under subsolidus conditions. Consequently, the modelled $\mathrm{H}_{2} \mathrm{O}$ values are slightly higher than those determined by Holtz et al. (2001), and the effect is most pronounced near the solidus (Fig. 8).

Liquidus curves correspond to the minimum amount of water that the magma can hold under equilibrium conditions (Holtz et al. 2001). Thus, during thermal equilibration, the curves constrain the maximum amount of melting that can 
occur depending on the initial water content of the sourcerock (Fig. 7b), because the crust continues to melt until all the $\mathrm{H}_{2} \mathrm{O}$ is consumed. Using the liquidus curves from Holtz et al. (2001), it appears that the deeper (4-8 kbar) GTI magmas contained 5-7 wt $\%$ water, whereas the subvolcanic magmas from the western domain were drier, containing $\sim 3$ wt\% water at emplacement (Fig. 8). In this scenario, magmas containing $\sim 7 \mathrm{wt} \% \mathrm{H}_{2} \mathrm{O}$ in the middle to deep crust would potentially stall at $\sim 5 \mathrm{kbar}$, because they are close to water saturation, and build cool $\left(\sim 730^{\circ} \mathrm{C}\right)$, hydrous $(\sim 7$ wt $\%)$, crystal-rich (i.e. crystal mush) magma chambers. Accordingly, a magma-rich middle crust was likely to form, as observed in the central domain of the GTI. A modern analogue is the Altiplano-Puna Magma Body (APMB) of the Andes, South America, which contains $7-10 \mathrm{wt} \% \mathrm{H}_{2} \mathrm{O}$ and resides in the middle crust between 15 and $20 \mathrm{~km}$ depth (Laumonier et al. 2017).

On the other hand, the inferred water content of the Croydon volcanic rocks and the western granites is $\sim 3 \mathrm{wt} \% \mathrm{H}_{2} \mathrm{O}$ at eruption (Fig. 8), which implies that these magmas were much hotter and drier. If these magmas rose adiabatically from the lower GTI crust (8-9 kbar), their initial water content was $\sim 4 \mathrm{wt} \% \mathrm{H}_{2} \mathrm{O}$ and they were at least $100{ }^{\circ} \mathrm{C}$ hotter $\left(800-850^{\circ} \mathrm{C}\right)$ than the temperature estimates from the Einasleigh Metamorphics (Volante et al. 2020a). Thus, it would seem that additional heat was required to generate the western domain magmas, possibly caused by injections of mafic magmas, as indicated by the presence of mafic enclaves in these rocks (e.g., Fig. 2e).

\section{Revised monazite thermometry}

Thermodynamic modelling provides an independent tool to evaluate the water content of magmas generated at middle and lower-crustal levels in the GTI (Fig. 6). We now use these inferred $\mathrm{H}_{2} \mathrm{O}$ contents to re-assess monazite saturation temperatures $\left(T_{\mathrm{mz}}\right)$ in the GTI. Upper crustal granites have 4 $\mathrm{wt} \% \mathrm{H}_{2} \mathrm{O}$, whereas middle to lower-crustal granites have 7 wt $\% \mathrm{H}_{2} \mathrm{O}$. The revised $T_{\mathrm{mz}}$ calculations (full results are listed in the Electronic supplementary material Table S6) provide a range of temperatures between $700-810^{\circ} \mathrm{C}$ (Fig. 6c), with one volcanic outlier of $\sim 870^{\circ} \mathrm{C}$ and only two values below the $\sim 660{ }^{\circ} \mathrm{C}$ solidus at $5 \mathrm{kbar}$.

The Croydon volcanic rocks record an average $T_{\mathrm{mz}}$ of $\sim 790 \pm 38{ }^{\circ} \mathrm{C}$ (Fig. 6c), and overlap with the western domain plutons (i.e., Esmeralda, Olsen and Macartney), which have an average $T_{\mathrm{mz}}$ of $\sim 750 \pm 37{ }^{\circ} \mathrm{C}, \sim 795 \pm 16{ }^{\circ} \mathrm{C}$ and $\sim 770 \pm 26^{\circ} \mathrm{C}$, respectively. On the other hand, the $T_{\mathrm{mz}}$ for the granites from the central domain (Forsayth, Goldsmiths, and Delaney) have lower average values $\left(\sim 713 \pm 49^{\circ} \mathrm{C}, \sim 715 \pm 60{ }^{\circ} \mathrm{C}\right.$ and $730 \pm 29^{\circ} \mathrm{C}$, respectively) than the magmatic intrusions in the western domain, but have similar values to the $T_{\mathrm{zr}}$ obtained for the same samples.
The leucocratic layers in the eastern domain yield $T_{\mathrm{mz}}$ of $775 \pm 60{ }^{\circ} \mathrm{C}$, comparable to the $T_{\mathrm{mz}}$ values recorded by the granitic and volcanic samples in the western domain (for $\sim 4 \mathrm{wt} \% \mathrm{H}_{2} \mathrm{O}$ ). Hence, the revised $T_{\mathrm{mz}}$ suggest lower temperatures $\left(\sim 700-730^{\circ} \mathrm{C}\right.$ and $\left.\sim 770-800{ }^{\circ} \mathrm{C}\right)$ for the more hydrous mid-to lower-crustal melts, whereas less significant variations are shown by the $T_{\mathrm{mz}} v$ alues obtained for the more anhydrous upper-crustal granitic and volcanic rocks (Fig. 6b and d). Nonetheless, $T_{\mathrm{mz}}$ values commonly represent the minimum magmatic temperatures and that can be seen in Fig. 8 where they generally overlap with the lower $T_{\text {(Ti-zr) }}$ temperature values of each pluton.

The revised $T_{\mathrm{mz}}$ values also show slightly better agreement with the zircon saturation thermometer $\left(T_{\text {zr }}\right)$ using water values of $\sim 4 \mathrm{wt} \%$ and $\sim 7 \mathrm{wt} \% \mathrm{H}_{2} \mathrm{O}$ determined for each domain (Fig. 6d), particularly in the case of the more hydrous melts of the central and eastern domains. The agreement between the $T_{\mathrm{mz}}$ (Montel 1993) and $T_{\mathrm{zr}}$ (Boehnke et al. 2013) for the GTI igneous complex is within $+40{ }^{\circ} \mathrm{C}$ (Fig. 6d), with few exceptions. However, it should be noted that the correlation coefficient for $T_{\mathrm{mz}}$ vs $T_{\mathrm{zr}}$ only improves from 0.72 assuming a water content of $1.5 \mathrm{wt} \% \mathrm{H}_{2} \mathrm{O}$ (Fig. 6d) to 0.76 if the higher and more variable water contents are used (Fig. 6d).

\section{Use and misuse of geothermometers}

Recent investigations on the Ti-in-zircon calculations argued that magmatic temperatures in S-type (peraluminous) granitic magmas are commonly underestimated (Schiller and Finger 2019). The latter study was applied on the Weinsberg granite suite of the South Bohemian Batholith, Czech Republic, which was considered to be generated by fluidabsent melting of biotite-quartz-plagioclase assemblages in the lower crust (Finger and Clemens 1995). Schiller and Finger (2019) suggested that an $a_{\mathrm{TiO} 2}$ of $0.1-0.5$ should be considered for granitic rocks and that a final correction of $+70{ }^{\circ} \mathrm{C}$ should be applied to obtain more plausible Ti-inzircon temperatures to better fit with the zircon saturation temperature model of Watson and Harrison (1983). However, use of low $a_{\mathrm{TiO} 2}$ values for the Weinsberg granite produced temperatures of $>850{ }^{\circ} \mathrm{C}$ that are much higher than the $P-T$ conditions estimated for the surrounding cordierite-garnet-K-feldspar diatexite $\left(\sim 5 \mathrm{kbar}\right.$ and $\sim 750-800{ }^{\circ} \mathrm{C}$; Finger and Clemens 1995) and $\sim 50{ }^{\circ} \mathrm{C}$ higher than zircon saturation temperatures, if the updated zircon solubility calibration (Boehnke et al. 2013) is used. We suggest that the diatexite, which is a melt-rich migmatite, more closely reflects the temperature of the S-type magma generation.

Furthermore, a recent study (Siégel et al. 2018) claimed that zircon geothermometers (i.e., $T_{\mathrm{zr}}$ and $T_{(\mathrm{Ti}-\mathrm{zr})}$ ) have been misused in the literature. They emphasized that $T_{\mathrm{zr}}$ is a theoretical temperature that cannot be used as a magmatic 
temperature estimate because bulk-rock compositions of plutonic rocks do not represent the melt compositions from which the zircon grew. Their conclusion about the perceived unreliability of zircon-based geothermometers is primarily based on the assumption that granites form due to the breakdown of hydrous minerals under fluid absent/dehydration melting conditions at temperatures of $\sim 850{ }^{\circ} \mathrm{C}$ (e.g., Clemens et al. 2020 and reference therein) and crystallise over an extended temperature interval. Indeed, dehydration melting at high temperatures $\left(>800^{\circ} \mathrm{C}\right)$ is a prerequisite to produce voluminous S-type granites through dehydration, unless water-fluxed melting is invoked (e.g., Collins et al. 2016; Weinberg and Hasalová 2015).

Our study shows that the GTI igneous complex requires $\mathrm{H}_{2} \mathrm{O}$-enhanced melt conditions to produce sufficient granitic melts. If they had formed solely by mica breakdown, the melt volumes at $730{ }^{\circ} \mathrm{C}$ would be $\sim 15-17 \%$ (Fig. 7b), which is too low to account for the extensive S-type magmatism in the GTI (Fig. 1). Rather, small addition of water readily increase the melt volumes, which also explains the low temperatures of magma equilibration and the high water content $\left(\sim 7 \mathrm{wt} \% \mathrm{H}_{2} \mathrm{O}\right)$ of the GTI magmas This is consistent with recent studies in the GTI (Pourteau et al. 2020), where fluidpresent melt conditions were suggested to explain the formation of low- $T$ trondhjemitic melts.

In light of our results, recent models for Ti-in-zircon calculations (Schiller and Finger 2019) and critiques on zircon-based thermometry should re-evaluate the assumption that S-type granite generation occurs by high-temperature fractionation or dehydration melting, and other processes such as fluid-fluxed melting within a fertile crust should be considered. Certainly, a comparison of zircon versus monazite saturation temperatures, particularly if combined with Ti-in-zircon thermometry, would help determine whether open-system water fluxing is necessary for S-type magma generation.

Our study indicates that the entire compositional spectrum of each granite suite needs to be considered for zircon saturation temperatures to be properly assessed, not just individual samples. This is because many granitic magmas are mixtures of melt and restitic minerals (e.g., Chappell et al. 1987; Clemens and Stevens 2012; White and Chappell 1977), which is also demonstrated by our thermodynamic modelling (Fig. 7). Accordingly, individual samples only reflect part of the system, and it is necessary to use the most mafic granites of a granite suite to estimate peak temperatures of magma generation (e.g., Collins et al. 1982, 2016). Indeed, if those mafic S-type magmas still contain inherited zircon cores, $T_{\mathrm{zr}}$ is a maximum estimate of magma generation.

The peak $T_{\mathrm{zr}}$ temperatures and $T_{\mathrm{mz}}$ in the GTI granites closely correspond to the average $T_{(\mathrm{Ti}-\mathrm{zr})}$ temperatures (Fig. 5c), which we suggest were the temperatures of thermal equilibration in the crust, at least for the middle and lower crust (Table S7). Only the subvolcanic or volcanic rocks of the western domain were not in thermal equilibrium. Nonetheless, $T_{\text {(Ti-zr) }}$ temperatures peak at $\sim 900{ }^{\circ} \mathrm{C}$ in the eastern and western magmas (Fig. 5c), suggesting that the lower-crustal ( $8-9 \mathrm{kbar})$ source region of the GTI was subjected to transient influxes of hot mafic magma. This mafic component is evident from the presence of mafic enclaves, and by the more radiogenic $\mathrm{Hf}$ isotopic composition of the western domain rocks (Nordsvan 2020).

\section{Conclusions}

Strongly-peraluminous (S-type) granites in the Georgetown Inlier were generated within $\sim 30 \mathrm{~km}$-thick Proterozoic crust. SHRIMP U-Pb geochronology of monazite and zircon indicates synchronous crystallisation at $c .1550 \mathrm{Ma}$ for granites that were emplaced from deep (6-9 kbar), through the middle (4-6 kbar), to upper ( $0-4$ kbar) crustal levels. By applying zircon and monazite thermometry combined with phase equilibrium modelling to granites and volcanic rocks of the GTI, this study highlights the following:

- Most S-type granites in the GTI were generated in the middle crust, at low temperature $\left(\sim 730{ }^{\circ} \mathrm{C}\right)$, probably during $\mathrm{H}_{2} \mathrm{O}$-fluxed melting.

- Modelled melt compositions (from phase equilibria calculations) obtained at $5 \mathrm{kbar}$ between 690 and $850{ }^{\circ} \mathrm{C}$ overlap with the array of compositions of the GTI granite suites at the lower end of the temperature spectrum, rather than at the higher end.

- Harker diagrams highlight that the GTI S-type granites are mushes containing a mixture of melts and residual crystals such as garnet, biotite, plagioclase and zircon, and cannot be treated as melts.

- $T_{(\mathrm{Ti}-\mathrm{zr})}$ temperature range recorded within each pluton reflects thermal fluctuations in the magma chamber, whereas $T_{\mathrm{zr}}$ values appear to reflect ambient (equilibrium) conditions in the respective magma chambers.

- For effective use of the zircon saturation geothermometers, the entire compositional spectrum of each granite suite needs to be considered.

- Zircon saturation $\left(T_{\mathrm{zr}}\right)$ values for felsic intrusive and effusive rocks at deep, middle and upper-crustal levels generally represent average $T_{\text {(Ti-zr) }}$ temperatures, when $a_{\mathrm{TiO} 2}=0.9 / 1$ is used for Ti-in-zircon thermometry. Suggestions for using lower $a_{\mathrm{TiO} 2}$ values for S-type magmas do not seem necessary.

- Phase equilibria modelling is an independent method for constraining water content in granitic magmas. 
- Monazite saturation temperature $\left(T_{\mathrm{mz}}\right)$ values better agree with $T_{\mathrm{zr}}$ estimates when variable $\mathrm{H}_{2} \mathrm{O}$ contents are applied to the $T_{\mathrm{mz}}$ calculations.

- $\mathrm{Cool}\left(\sim 730-750{ }^{\circ} \mathrm{C}\right)$ and hydrous $\left(\sim 7 \mathrm{wt} \% \mathrm{H}_{2} \mathrm{O}\right)$ granitic magmas existed in the middle crust ( $\sim 5 \mathrm{kbar})$, whereas hotter $\left(>800{ }^{\circ} \mathrm{C}\right)$ and drier $\left(\sim 4 \mathrm{wt} \% \mathrm{H}_{2} \mathrm{O}\right)$ magmas reached the near-surface or erupted, with the necessary additional heat derived from more mafic, mantle-like magmas.

- The inferred hydrous mid-crustal magma chamber of the GTI has a modern analogue in the Andean arc system of South America.

\begin{abstract}
Acknowledgments We thank all the landowners of the Etheridge Province for their hospitality and logistic help during our fieldwork campaigns, with a specific thanks to Peter and Simon Terry. We would like to thank Brad J. McDonald for his valuable support and assistance with sample preparation and the analytical facilities, Luc-Serge Doucet and Roberto Weinberg for important suggestions and fruitful discussions, Hamed Mohammed Gamal El Dien for his valuable help with sample preparation for analytical analyses, Allen Kennedy and Michael Wingate for valuable comments and suggestions for the SHRIMP data acquisition and processing. We are grateful to Daniela Rubatto for her supportive feedback on the manuscript. We also thank Fritz Finger and an anonymous reviewer for providing stimulating comments on the manuscript.
\end{abstract}

Funding Open Access funding enabled and organized by Projekt DEAL. This project was funded by the Australian Research Council Laureate Fellow grant to Zheng-Xiang Li (FL150100133). This is contribution 1537 from the ARC Centre of Excellence for Core to Crust Fluid Systems (https://www.ccfs.mq.edu.au) and a contribution to IGCP648 Supercontinent Cycles and Global Geodynamics. GeoHistory Facility instruments in the JdLC, Curtin University were funded via an Australian Geophysical Observing System grant provided to AuScope Pty Ltd. by the AQ44 Australian Education Investment Fund program. Research in the JdLC GeoHistory laser ablation Facility is enabled by AuScope (auscope.org.au) and the Australian Government via the National Collaborative Research Infrastructure Strategy (NCRIS).

\section{Compliance with ethical standards}

Conflict of interest The author(s) declare that they have no competing interests.

Open Access This article is licensed under a Creative Commons Attribution 4.0 International License, which permits use, sharing, adaptation, distribution and reproduction in any medium or format, as long as you give appropriate credit to the original author(s) and the source, provide a link to the Creative Commons licence, and indicate if changes were made. The images or other third party material in this article are included in the article's Creative Commons licence, unless indicated otherwise in a credit line to the material. If material is not included in the article's Creative Commons licence and your intended use is not permitted by statutory regulation or exceeds the permitted use, you will need to obtain permission directly from the copyright holder. To view a copy of this licence, visit http://creativecommons.org/licenses/by/4.0/.

\section{References}

Acosta-Vigil A, Buick I, Hermann J, Cesare B, Rubatto D, London D, Morgan GB (2010) Mechanisms of crustal anatexis: a geochemical study of partially melted metapelitic enclaves and host dacite. SE Spain J Petrol 51:785-821

Anders E, Grevesse N (1989) Abundances of the elements: meteoritic and solar. Geochim Cosmochim Acta 53:197-214. https://doi. org/10.1016/0016-7037(89)90286-X

Baker MJ, Crawford AJ, Withnall IW (2010) Geochemical, Sm-Nd isotopic characteristics and petrogenesis of Paleoproterozoic mafic rocks from the Georgetown Inlier, NORTH Queensland: implications for relationship with the Broken Hill and Mount Isa Eastern Succession. Precambrian Res 177:39-54

Black LP, McCulloch MT (1990) Isotopic evidence for the dependence of recurrent felsic magmatism on new crust formation: an example from the Georgetown region of northeastern Australia. Geochim Cosmochim Acta 54:183-196

Black LP, Withnall IW (1993) The ages of Proterozoic granites in the Georgetown Inlier of northeastern Australia, and their relevance to the dating of tectonothermal events AGSO. J Austr Geol Geophys 14:331-341

Black LP, Withnall IW, Gregory P, Oversby BS, Bain JHC (2005) U-Pb zircon ages from leucogneiss in the Etheridge Group and their significance for the early history of the Georgetown region, north Queensland Australian. J Earth Sci 52:385-401

Boehnke P, Watson EB, Trail D, Harrison TM, Schmitt AK (2013) Zircon saturation re-revisited. Chem Geol 351:324-334

Boger SD, Hansen D (2004) Metamorphic evolution of the Georgetown Inlier, northeast Queensland, Australia; evidence for an accreted Palaeoproterozoic terrane? J Metamorph Geol 22:511-527

Brown M, Raith M (1996) First evidence of ultrahigh-temperature decompression from the granulite province of southern India. $\mathrm{J}$ Geol Soc 153:819-822

Champion DC (1991) The felsic granites of far north Queensland [Geology PhD]. Australian National University, Canberra. https ://doi.org/10.25911/5d7787810520e

Champion DC, Budd AR, Hazell MS, Sedgmen A (2007) OZCHEM National Whole Rock Geochemistry Dataset. Geoscience Australia, Canberra. http://pid.geoscience.gov.au/dataset/ga/65464

Chappell BW (1984) Source rocks of I- and S-type granites in the Lachlan Fold Belt, southeastern Australia. Philos Trans R Soc Lond Ser A Math Phys Eng Sci 310:693-707

Chappell BW, White AJR (1992) I-and S-type granites in the Lachlan Fold Belt. Earth Environ Sci Trans R Soc Edinburgh 83:1-26

Chappell BW, White AJR, Wyborn D (1987) The importance of residual source material (restite) in granite petrogenesis. J Petrol 28:1111-1138

Chappell BW, Bryant CJ, Wyborn D, White AJR, Williams IS (1998) High-and low-temperature I-type granites. Resour Geol 48:225-235

Clemens JD (1984) Water contents of silicic to intermediate magmas. Lithos 17:273-287

Clemens JD, Stevens G (2012) What controls chemical variation in granitic magmas? Lithos 134:317-329

Clemens JD, Stevens G, Bryan SE (2020) Conditions during the formation of granitic magmas by crustal melting-hot or cold; drenched, damp or dry? Earth Sci Rev 200:102982

Collins WJ, Beams SD, White AJR, Chappell BW (1982) Nature and origin of A-type granites with particular reference to southeastern. Austr Contrib Miner Petrol 80:189-200

Collins WJ, Huang H-Q, Jiang X (2016) Water-fluxed crustal melting produces Cordilleran batholiths. Geology 44:143-146 
Connolly JAD, Petrini K (2002) An automated strategy for calculation of phase diagram sections and retrieval of rock properties as a function of physical conditions. J Metamorph Geol 20:697-708

Ferry JM, Watson EB (2007) New thermodynamic models and revised calibrations for the Ti-in-zircon and $\mathrm{Zr}$-in-rutile thermometers. Contrib Miner Petrol 154:429-437

Finger F, Clemens JD (1995) Migmatization and "secondary" granitic magmas: effects of emplacement and crystallization of "primary" granitoids in Southern Bohemia. Austria Contrib Mineral Petrol 120:311-326

Fu B, Page FZ, Cavosie AJ, Fournelle J, Kita NT, Lackey JS, Wilde SA, Valley JW (2008) Ti-in-zircon thermometry: applications and limitations. Contrib Miner Petrol 156:197-215

Gualda GAR, Ghiorso MS, Lemons RV, Carley TL (2012) RhyoliteMELTS: a modified calibration of MELTS optimized for silicarich, fluid-bearing magmatic systems. J Petrol 53:875-890

Harley SL (2008) Refining the P-T records of UHT crustal metamorphism. J Metamorphic Geol 26:125-154

Hayden LA, Watson EB (2007) Rutile saturation in hydrous siliceous melts and its bearing on Ti-thermometry of quartz and zircon. Earth Planet Sci Lett 258:561-568

Holland TJB, Powell R (2011) An improved and extended internally consistent thermodynamic dataset for phases of petrological interest, involving a new equation of state for solids. J Metamorphic Geol 29:333-383

Holtz F, Johannes W, Tamic N, Behrens H (2001) Maximum and minimum water contents of granitic melts generated in the crust: a reevaluation and implications. Lithos 56:1-14

Hoskin PWO, Schaltegger U (2003) The composition of zircon and igneous and metamorphic petrogenesis. Rev Miner Geochem $53: 27-62$

Johnson TE, White RW, Powell R (2008) Partial melting of metagreywacke: a calculated mineral equilibria study. J Metamorphic Geol 26:837-853

Jung S, Pfander JrA (2007) Source composition and melting temperatures of orogenic granitoids: constraints from $\mathrm{CaO} / \mathrm{Na} 2 \mathrm{O}, \mathrm{Al} 2 \mathrm{O} 3 /$ $\mathrm{TiO} 2$ and accessory mineral saturation thermometry. Eur J Miner 19:859-870

Kemp AIS, Whitehouse MJ, Hawkesworth CJ, Alarcon MK (2005) A zircon U-Pb study of metaluminous (I-type) granites of the Lachlan Fold Belt, southeastern Australia: implications for the high/low temperature classification and magma differentiation processes. Contrib Miner Petrol 150:230-249

Laumonier M, Gaillard F, Muir D, Blundy J, Unsworth M (2017) Giant magmatic water reservoirs at mid-crustal depth inferred from electrical conductivity and the growth of the continental crust. Earth Planet Sci Lett 457:173-180

Le Breton N, Thompson AB (1988) Fluid-absent (dehydration) melting of biotite in metapelites in the early stages of crusral anatexis. Contrib Miner Petrol 99:226-237

McDowell SM, Miller CF, Mundil R, Ferguson CA, Wooden JL (2014) Zircon evidence for a $200 \mathrm{ky}$ supereruption-related thermal flareup in the Miocene southern Black Mountains, western Arizona. USA Contrib Miner Petrol 168:1031

Miller CF, McDowell SM, Mapes RW (2003) Hot and cold granites? Implications of zircon saturation temperatures and preservation of inheritance. Geology 31:529-532

Montel J-M (1993) A model for monazite/melt equilibrium and application to the generation of granitic magmas. Chem Geol 110:127-146

Neumann NL, Kositcin N (2011) New SHRIMP U-Pb zircon ages from north Queensland, 2007-2010 Record 2011/38:82 pp

Nordsvan AR (2020) Sedimentology and provenance of NE Australian Proterozoic basins with relevance to the formation of the Supercontinent Nuna School of Earth and Planetary Sciences, Curtin University, Perth, p 217
Patiño Douce AE, Harris N (1998) Experimental constraints on Himalayan anatexis. J Petrol 39:689-710

Pourteau A et al (2020) TTG generation by fluid-fluxed crustal melting: Direct evidence from the Proterozoic Georgetown Inlier. NE Austr Earth Planet Sci Lett 550:116548

Rubatto D (2002) Zircon trace element geochemistry: partitioning with garnet and the link between $\mathrm{U}-\mathrm{Pb}$ ages and metamorphism. Chem Geol 184:123-138. https://doi.org/10.1016/S0009 $-2541(01) 00355-2$

Schiller D, Finger F (2019) Application of Ti-in-zircon thermometry to granite studies: problems and possible solutions. Contrib Miner Petrol 174:51

Sengupta P, Sen J, Dasgupta S, Raith M, Bhui UK, Ehl J (1999) Ultra-high temperature metamorphism of metapelitic granulites from Kondapalle, Eastern Ghats Belt: implications for the IndoAntarctic correlation. J Petrol 40:1065-1087

Siégel C, Bryan SE, Allen CM, Gust DA (2018) Use and abuse of zircon-based thermometers: a critical review and a recommended approach to identify antecrystic zircons. Earth Sci Rev $176: 87-116$

Stepanov AS, Hermann J, Rubatto D, Rapp RP (2012) Experimental study of monazite/melt partitioning with implications for the REE, Th and U geochemistry of crustal rocks. Chem Geol 300:200-220

Vernon RH (1984) Microgranitoid enclaves in granites-globules of hybrid magma quenched in a plutonic environment. Nature 309:438-439

Vernon RH (2004) A practical guide to rock microstructure. Cambridge University Press, Cambridge, p 594

Vielzeuf D, Montel JM (1994) Partial melting of metagreywackes. Part I Fluid-absent experiments and phase relationships. Contrib Miner Petrol 117:375-393

Vielzeuf D, Clemens JD, Pin C, Moinet E (1990) Granites, granulites, and crustal differentiation. Granulites and crustal evolution. Springer, Berlin, pp 59-85

Volante S, Collins WJ, Pourteau A, Li ZX, Li J, Nordsvan AR (2020) Structural evolution of a $1.6 \mathrm{Ga}$ orogeny related to the final assembly of the supercontinent Nuna: coupling of episodic and progressive deformation. Tectonics 2020:06162. https://doi. org/10.1029/2020TC006162

Volante S et al (2020) Multiple P-T-d-t paths reveal the evolution of the final Nuna assembly in northeast Australia. J Metamorphic Geol. https://doi.org/10.1111/jmg.12532

Watson EB, Harrison TM (1983) Zircon saturation revisited: temperature and composition effects in a variety of crustal magma types. Earth Planet Sci Lett 64:295-304

Watson EB, Harrison TM (2005) Zircon thermometer reveals minimum melting conditions on earliest. Earth Sci (N Y) 308:841-844. https ://doi.org/10.1126/science.1110873

Watson EB, Wark DA, Thomas JB (2006) Crystallization thermometers for zircon and rutile. Contrib Miner Petrol 151:413-433. https:// doi.org/10.1007/s00410-006-0068-5

Webb G, Powell R, McLaren S (2015) Phase equilibria constraints on the melt fertility of crustal rocks: the effect of subsolidus water loss. J Metamorphic Geol 33:147-165

Weinberg RF, Hasalová P (2015) Water-fluxed melting of the continental crust: a review. Lithos 212:158-188

Wheller CJ, Powell R (2014) A new thermodynamic model for sapphirine: calculated phase equilibria in $\mathrm{K} 2 \mathrm{O}-\mathrm{FeO}-\mathrm{MgO}-\mathrm{Al} 2 \mathrm{O} 3-$ $\mathrm{SiO} 2-\mathrm{H} 2 \mathrm{O}-\mathrm{TiO} 2-\mathrm{Fe} 2 \mathrm{O} 3$. J Metamorph Geol 32:287-299

White AJR, Chappell BW (1977) Ultrametamorphism and granitoid genesis. Tectonophysics 43:7-22

White RW, Powell R, Holland TJB (2007) Progress relating to calculation of partial melting equilibria for metapelites. J Metamorphic Geol 25:511-527 
White RW, Powell R, Johnson TE (2014) The effect of Mn on mineral stability in metapelites revisited: new $\mathrm{a}-\mathrm{x}$ relations for manganese-bearing minerals. J Metamorphic Geol 32:809-828

Whitney DL, Evans BW (2010) Abbreviations for names of rock-forming minerals. Am Miner 95:185-187

Withnall IW (1985) Geochemistry and tectonic significance of proterozoic rocks from the Georgetown Inlier, north Queensland Bureau of mineral resources. J Austr Geol Geophys 9:339-351

Withnall IW, Hutton LJ (2013) Chapter 2 North Australian Craton. In: Jell PA (ed) Geology of Queensland. Department of Natural Resources and Mines, Queensland, pp 23-112
Withnall IW, Bain JHC, Draper JJ, MacKenzie DE, Oversby BS (1988) Proterozoic stratigraphy and tectonic history of the Georgetown Inlier, northeastern Queensland. Precambrian Res 40(41):429-446

Publisher's Note Springer Nature remains neutral with regard to jurisdictional claims in published maps and institutional affiliations. 